\title{
Proefonderzoek arbeidsmarktscanner afgestudeerden Rijksuniversiteit Limburg
}

Citation for published version (APA):

Ramaekers, G. W. M., \& Heijke, J. A. M. (1990). Proefonderzoek arbeidsmarktscanner afgestudeerden Rijksuniversiteit Limburg. Researchcentrum voor Onderwijs en Arbeidsmarkt, Faculteit der Economische Wetenschappen. ROA Working Papers No. 3 https://doi.org/10.26481/umarow.1990003

Document status and date:

Published: 01/01/1990

DOI:

10.26481/umarow.1990003

Document Version:

Publisher's PDF, also known as Version of record

\section{Please check the document version of this publication:}

- A submitted manuscript is the version of the article upon submission and before peer-review. There can be important differences between the submitted version and the official published version of record.

People interested in the research are advised to contact the author for the final version of the publication, or visit the DOI to the publisher's website.

- The final author version and the galley proof are versions of the publication after peer review.

- The final published version features the final layout of the paper including the volume, issue and page numbers.

Link to publication

\footnotetext{
General rights rights.

- You may freely distribute the URL identifying the publication in the public portal. please follow below link for the End User Agreement:

www.umlib.nl/taverne-license

Take down policy

If you believe that this document breaches copyright please contact us at:

repository@maastrichtuniversity.nl

providing details and we will investigate your claim.
}

Copyright and moral rights for the publications made accessible in the public portal are retained by the authors and/or other copyright owners and it is a condition of accessing publications that users recognise and abide by the legal requirements associated with these

- Users may download and print one copy of any publication from the public portal for the purpose of private study or research.

- You may not further distribute the material or use it for any profit-making activity or commercial gain

If the publication is distributed under the terms of Article $25 \mathrm{fa}$ of the Dutch Copyright Act, indicated by the "Taverne" license above, 


\section{PROEFONDERZOEK ARBEIDSMARKTSCANNER AFGESTUDEERDEN RIJKSUNIVERSITEIT LIMBURG}

$$
\text { ROA-W-1990/3 }
$$

G.W.M. Ramaekers en J.A.M. Heijke 
CIP-GEGEVENS KONINKLIJKE BIBLIOTHEEK, DEN HAAG

Ramaekers, G.W.M.

Proefonderzoek arbeidsmarktscanner afgestudeerden, Rijksuniversiteit Limburg/ G.W.M. Ramaekers en J.A.M. Heijke. -Maastricht: Researchcentrum voor Onderwijs en Arbeidsmarkt, Faculteit der Economische Wetenschappen, Rijksuniversiteit Limburg. - (Werkdocument/Researchcentrum voor Onderwijs en Arbeidsmarkt, ISSN 0922-4645; 1990/3)

Met 1it. opg.

ISBN $90-5321-032-6$ in spiraalband

SISO 318.7 UDC $681.324:[331.5: 378.22](492 * 6200)$

Trefw.: universitair onderwijs en arbeidsmarkt; Maastricht; onderzoek. 
1. INLEIDING 1

1.1. Doelstelling en relevantie van het informatiesysteem 1

1.2. Benodigde gegevens 2

1.3. Indeling van het rapport 3

2. DE VRAGENLIJSTEN 5

2.1. Systematiek 5

2.2. Inhoud en samenstelling van de vragenlijsten 6

3. DE PROEFENQUETE 8

3.1. Het testen van de vragenlijst 8

3.2. Respons en rappellering 8

4. PRESENTATIE VAN DE ONDERZOEKSRESULTATEN 11

4.1. Inleiding 11

4.2. Deelname aan het arbeidsproces 11

4.2.1. Arbeidssituatie 12

4.2.2. Mobiliteit 13

4.2.3. Functieverwerving 13

4.2.4. Dienstverband 14

4.2.5. Deeltijdfuncties 15

4.3. Functiekenmerken 15

4.3.1. Grootte van de werkorganisatie 16

4.3.2. Marktsector 16

4.3.3. Beroep 18

4.3.4. Leidinggeven 20

4.3.5. Inkomen 20

4.4. Aanvullende opleidingen 21

4.5. Aktiviteiten voor afgestudeerden 23

5. BEVINDINGEN 24

5.1. Dataverzameling en -verwerking 24

5.2. Bijstelling van de basisvragenkaart 24

5.3. Onderzoeksaktiviteiten in $1990 \quad 27$ 
BIJLAGE I De in de proefenquête geteste basisvragenkaart en toelichting op de basisvragenkaart

BIJLAGE II De naar aanleiding van de proefenquête opgestelde basisvragenlijst

BIJLAGE III Jaarkaart en toelichting op de jaarkaart 
VERANTWOORDING

In het najaar van 1988 verleende het College van Bestuur van de Rijksuniversiteit Limburg ( $R L$ ) aan het Researchcentrum voor Onderwijs en Arbeidsmarkt van de Faculteit der Economische Wetenschappen van de RL opdracht om een systeem voor 'follow-up' onderzoek onder afgestudeerden van deze universiteit op te zetten. Doel van dit systeem is het systematisch en periodiek beschikbaar doen komen van informatie over de positie op de arbeidsmarkt van de afgestudeerden en het functioneren van de alumni in de beroepspraktijk. Het onderzoekproject is van start gegaan in januari 1989 voor de duur van vooralsnog twee jaar. In dit werkdocument wordt het ontwikkelde onderzoekinstrument gepresenteerd en wordt verslag gedaan van de bevindingen van een proefenquête onder afgestudeerden die in dit kader is verricht.

De projectleiding van het onderzoek is in handen van prof. dr. J.A.M. Heijke. De uitvoering ervan berust bij drs. G.W.M. Ramaekers, daarbij ondersteund door J.M.J.A. Pisters.

Het onderzoekproject wordt begeleid door een commissie. Deze begeleidingscommissie bestaat uit de volgende personen:

Prof. dr. A.J. Boon, Faculteit der Gezondheidswetenschappen;

Dr. P.A.J. Bouhuijs, vakgroep Onderwijsontwikkeling en Onderwijsresearch;

Prof. dr. H.F.J.M. Crebolder, Faculteit der Geneeskunde;

C.A. van der Hucht, voorzitter, dienst Planning Ontwikkeling en Beleid;

Prof.dr. J.D.P. Kasper, Faculteit der Economische Wetenschappen;

Dr. P. Mostert, Faculteit der Algemene Wetenschappen;

Prof. mr. N.H.M. Roos, Faculteit der Rechtsgeleerdheid;

M.J.M. Zwanenburg, dienst Studentenzaken. 

SAMENVATTING

In deze eerste rapportage in het kader van het project 'Follow-up onderzoek afgestudeerden Rijksuniversiteit Limburg' wordt het informatiesysteem gepresenteerd waarmee een aantal gedetailleerde gegevens over de arbeidsmarktpositie van de afgestudeerden systematisch en periodiek kan worden gegenereerd. Daartoe zijn twee vragenlijsten ontwikkeld waarmee afgestudeerden periodiek kunnen worden bevraagd. De vragenlijsten zijn getest in een proefenquête onder een aantal afgestudeerden van de Rijksuniversiteit Limburg. Dit rapport doet verslag van het ontwikkelde onderzoeksinstrument en van de resultaten van de proefenquête.

AANGEZIEN HET GAAT OM EEN PROEFENQUETE DIE ONDER EEN BEPERKT AANTAL AFGESTUDEERDEN IS VERRICHT, HEBBEN DE IN DIT RAPPORT GEPRESENTEERDE ONDERZOEKSRESULTATEN SLECHTS EXEMPLARISCHE WAARDE. 
1. INLEIDING

\subsection{Doelstelling en relevantie van het informatiesysteem}

In het 'Ontwikkelingsplan 1989-1992 Rijksuniversiteit Limburg' wordt vermeld dat de Rijksuniversiteit Limburg (RL) grote waarde hecht aan de afstemming van haar onderwijs op de eisen van de beroepspraktijk en de aansluiting van het onderwijs op de mogelijkheden van de arbeidsmarkt ${ }^{1}$. In verband daarmee heeft het College van Bestuur aan het Researchcentrum voor Onderwijs en Arbeidsmarkt (ROA) van de Faculteit der Economische Wetenschappen opdracht verleend een systeem voor periodiek 'follow-up' onderzoek onder afgestudeerden van de RL op te zetten. Doel van dit systeem is het systematisch en periodiek beschikbaar doen komen van informatie over de kansen op de arbeidsmarkt van de afgestudeerden en het functioneren van de alumni in de beroepspraktijk. Deze informatie kan belangrijke bijdragen leveren aan:

- het informeren van (aankomende) studenten, afgestudeerden, onderwijsgevenden en werkgevers over de arbeidsmarkt- en beroepsmogelijkheden van de bij de RL aanwezige studie- en afstudeerrichtingen;

- het beter aansluiten van het universitaire onderwijs op de mogelijkheden van de arbeidsmarkt;

- het opstellen van arbeidsmarktprognoses op het niveau van studierichtingen waarvoor de bestaande dataverzameling, middels de Enquête Beroepsbevolking van het CBS, vanwege het steekproefkarakter ontoereikend is;

- het vaststellen van de vereiste opleidingscapaciteit van de studierichtingen;

- het evalueren van de opzet en de inrichting van de curricula;

- het bewaken van de kwaliteit van het probleemgestuurde onderwijs.

Uit het bovenstaande overzicht van toepassingsgebieden kunnen mogelijke groepen belanghebbenden en hun informatiebehoefte worden afgeleid. De resultaten van het arbeidsmarktonderzoek onder afgestudeerden kunnen worden gebruikt bij onder meer de studie- en beroepskeuze, de arbeidsbemiddeling, de personeelsplanning, de capaciteitsplanning van het onderwijs, de opzet en inrichting van curricula, alsmede de kwaliteitsbewaking van het onderwijs.

1. Rijksuniversiteit Limburg (1988), blz. 33. 
Kiezers van een studie of beroep en degenen die hierbij een voorlichtende of bemiddelende taak hebben, hebben behoefte aan informatie over de (toekomstige) kansen op werk, de (toekomstige) beroepsmogelijkheden, het te verwerven inkomen en de carrièremogelijkheden na het volgen van de verschillende opleidingen. Werkgevers, waartoe ook de overheid behoort, hebben voor de realisering van een doelmatige personeelsopbouw behoefte aan informatie over de (toekomstige) uitstroom uit de verschillende opleidingen en de mogelijkheden van deze opleidingen tijdens de beroepsuitoefening. Voor universiteiten en faculteiten zijn arbeidsmarktgegevens over hun opleidingen van belang voor de bepaling van de capaciteit van de onderwijsvoorzieningen, de inrichting van het onderwijs en de kwaliteitsbewaking van het onderwijs. Capaciteitsplanners in het onderwijs hebben informatie nodig waarmee de capaciteit van de verschillende opleidingen beter kan worden afgestemd op de mogelijkheden van de arbeidsmarkt. Het betreft met name kwantitatieve gegevens over de omvang en samenstelling van de toekomstige uitstroom uit de diverse opleidingen en de vraag op de arbeidsmarkt naar deze opleidingen. Onderwijsgevenden en ontwerpers van curricula hebben vooral behoefte aan informatie waarmee zij het onderwijs inhoudelijk beter kunnen afstemmen op de eisen van de beroepspraktijk. Het gat hierbij om kwalitatieve informatie over de functie-uitoefening en de daarvoor benodigde kennis en vaardigheden.

Door middel van de op te zetten systematische peiling komen niet alleen periodiek actuele onderzoeksgegevens - die op de hiervoor genoemde gebieden kunnen worden toegepast - ter beschikking, maar ook een geactualiseerd adressenbestand van oud-studenten en hun werkgevers. Deze output van followup onderzoek kan te zijner tijd de basis vormen voor een scala van aktiviteiten met betrekking tot de alumni, zoals het doelgroep-gericht aanbieden van post-doctorale opleidingen, fundraising, het uitgeven van een magazine voor oud-studenten, profilering van de RL met betrekking tot onderwijs en onderzoek, het verwerven van derde-geldstroomonderzoeksopdrachten, etcetera.

\subsection{Benodigde gegevens}

Om in de genoemde informatiebehoefte te kunnen voorzien zijn gegevens nodig over:

1. de kansen op werk na het verlaten van de opleiding, in het bijzonder in de beroependomeinen waarop de desbetreffende opleidingen beogen aan te sluiten;

2. het te verwerven inkomen en de carrièremogelijkheden in deze beroependo- 
meinen;

3. de doelmatigheid van de opleiding in relatie tot de eisen die de beroepsuitoefening stelt.

De benodigde gegevens zullen worden verzameld middels een systematische peiling onder de afgestudeerden. Deze peiling bestaat uit een jaarlijkse schriftelijke bevraging van de alumni met betrekking tot hun positie op de arbeidsmarkt en de daarin opgetreden veranderingen (de bij 1 en 2 genoemde gegevens). De jaarlijkse bevraging zal meerjaarlijks worden aangevuld met additionele vragen over het verloop van de beroepscarrière en de rol hierbij van het genoten onderwijs (de bij 3 genoemde gegevens). Voor de jaarlijkse bevraging zijn vragenlijsten ontwikkeld en getest. Deze worden in hoofdstuk 2 besproken.

Met behulp van de jaarlijkse bevraging zullen kerngegevens worden verzameld over:

- het 'onderwijsverleden' van de afgestudeerde, in het bijzonder over de laatstgevolgde studie- en afstudeerrichting;

- de 'eerste bestemming' na het afronden van de opleiding, dat wil zeggen de belangrijkste soort bezigheden die een afgestudeerde na het afronden van de studie verricht.

Vervolgens indien men werkzaam is:

- de functie waarin men werkzaam is;

- de werkgever waarvoor men werkzaam is;

- de wijze waarop men in contact is gekomen met de huidige werkgever en de aard van de arbeidsovereenkomst;

- de arbeidsvoorwaarden;

- eventuele aanvullende opleidingen.

En indien men werkloos is:

- eventuele aanvullende opleidingen.

\subsection{Indeling van het rapport}

In hoofdstuk 2 wordt ingegaan op de ontwikkelde vragenlijsten.

De vragenlijsten zijn eerst getest in een proefenquête onder een aantal afgestudeerden van de Faculteit der Gezondheidswetenschappen (FdGW) en naar 
aanleiding daarvan bijgesteld. Vervolgens is met behulp van de bijgestelde vragenlijsten een proefenquête verricht onder een aantal afgestudeerden van de Faculteit der Geneeskunde ( $F d G)$, de Faculteit der Rechtsgeleerdheid ( $F d R$ ) en de Faculteit der Economische Wetenschappen (FdEW) ${ }^{2}$. In hoofdstuk 3 wordt verslag gedaan van deze proefenquête.

In hoofdstuk 4 wordt een indruk gegeven van de soort gegevens die met behulp van de eerste jaarlijkse bevraging zullen worden gegenereerd. De gegevens die bij de definitieve uitvoering van het project zullen worden verzameld geven meer informatie dan in dit hoofdstuk is opgenomen. De reden hiervoor is dat het hier gaat om gegevens die met behulp van een proefenquête onder een beperkt aantal afgestudeerden zijn verzameld. De hier gepresenteerde onderzoeksresultaten hebben daarom slechts exemplarische waarde.

In hoofdstuk 5 wordt een aantal bevindingen geformuleerd die uit de proefenquête naar voren zijn gekomen. Ook is in dit hoofdstuk een overzicht en tijdschema van geplande onderzoeksaktiviteiten voor 1990 opgenomen.

Dit werkdocument wordt afgesloten met een aantal bijlagen waarin de ontwikkelde vragenlijsten zijn opgenomen.

2. De jongste faculteit van de RL, de Faculteit der Algemene Wetenschappen, heeft (nog) geen eigen studenten. 


\section{DE VRAGENLIJSTEN}

\subsection{Systematiek}

De systematiek van het periodieke onderzoek onder de afgestudeerden bestaat hieruit dat de oud-studenten circa één jaar na hun afstuderen met behulp van een basisvragenkaart worden bevraagd en vervolgens jaarlijks met een beperkte jaarkaart waarmee zij mutaties kunnen doorgeven. De jaarkaart is een verkorte versie van de basisvragenkaart. In de laatstgenoemde vragenkaart is nog een aantal vragen opgenomen die voornamelijk betrekking hebben op de gevolgde studie. Beide vragenkaarten zijn voorzien van een toelichting op de vragen en op de antwoordmogelijkheden met de bijbehorende codes. Aan de afgestudeerden wordt gevraagd om de op hen van toepassing zijnde codes op de basisvragenkaart danwel jaarkaart aan te geven. Op de kaarten staat al een aantal antwoorden voorgedrukt. Op de basisvragenkaart zijn dat gegevens die door de dienst Studentenzaken zijn verstrekt. Op de jaarkaart staan de antwoorden voorgedrukt die in het voorgaande jaar door de respondenten zijn gegeven. Aan de geënquêteerden wordt verzocht om onvolledige of gewijzigde gegevens aan te vullen of te corrigeren.

Beide kaarten zijn mede ontwikkeld in het kader van een pilotstudie in de gezondheidswetenschappen naar de mogelijkheden om de arbeidsmarktpositie en loopbanen van afgestudeerden in kaart te brengen ${ }^{3}$. Bij de constructie van de vragenlijsten gold als uitgangspunt dat hiermee data kunnen worden voortgebracht die met andere gegevensbronnen zijn te vergelijken. Dit impliceert dat deze data op een methodisch verantwoorde wijze moeten worden verzameld en aansluiten op (inter)national gehanteerde definities van begrippen als werkloosheid en werkgelegenheid, en (inter)nationale classificaties van bijvoorbeeld opleiding, beroep en bedrijfstak. Om aan deze vereisten tegemoet te kunnen komen is een aantal veelgebruikte vragenlijsten geanalyseerd. Genoemd kunnen worden de vragenlijst van de Enquête Beroepsbevolking van het CBS en de vragenlijsten die worden gebruikt bij de loopbaanonderzoeken van de Stichting Maatschappelijke Plaats Wageningse Afgestudeerden (MPW). Het gebruik van basisvragenkaarten en jaarkaarten en de vormgeving ervan zijn afkomstig van de MPW. Voor de samenstelling van de classificaties is gebruik gemaakt van de standaardindelingen van het CBS.

3. Van Dam, Heijke en Ramaekers (1989). 
De in dit hoofdstuk voorgestelde jaarlijkse bevraging kan periodiek, bijvoorbeeld vijfjaarlijks, worden aangevuld met vragen over de beroepsmobiliteit, het verdere verloop van de beroepscarrière en eventuele andere thema's betreffende de aansluiting tussen onderwijs en arbeidsmarkt die men in deze vijfjaarlijkse bevraging aan de orde wil stellen.

\subsection{Inhoud en samenstelling van de vragenlijsten}

Op grond van de in paragraaf 1.2. genoemde benodigde informatie, en na bestudering van de eerder genoemde vragenlijsten, is besloten tot de volgende opbouw van zowel de basisvragenkaart als de jaarkaart:
a. persoonsgegevens;
b. opleidingsgegevens (alleen in de basisvragenkaart);
c. huidige arbeidsmarktsituatie;
d. kenmerken van beroep en functie;
e. organisatiekenmerken;
f. activiteiten (indien niet betaald werkzaam) en aanvullende opleidingen.

ad. a: Hier worden achtereenvolgens naam, voorletters, adres, postcode, woonplaats, land en telefoonnummer gevraagd. Het spreekt vanzelf dat de beschikbaarheid en de juistheid van deze gegevens een noodzakelijke voorwaarde vormt voor het welslagen van onderzoek onder afgestudeerden.

ad. $b$ : In de basisvragenkaart is, in aansluiting op de hiervoor genoemde persoonsgegevens, een aantal vragen opgenomen over de (op dat moment onveranderlijk geworden) persoonsgegevens zoals geboortejaar, geslacht, vooropleiding, de reeds aanwezige werkervaring op het moment van afstuderen en de belangrijkste bezigheden, per maand, tussen het moment van afstuderen en het moment van enquêteren. Verder bevat dit vragenblok vragen over de gevolgde studie- en afstudeerrichting(-en) en de data van aanvang en voltooiing van de studie. Al deze gegevens zijn, met uitzondering van de reeds aanwezige werkervaring op het moment van afstuderen en de vraag naar de bezigheden na het afstuderen, bekend bij de administratie van de dienst Studentenzaken. De vragen over de voltooide studie- en afstudeerrichting zijn open. De antwoorden worden gecodeerd aan de hand van een indeling die is gebaseerd op de Standaard Onderwijs Indeling (SOI) van het CBS. Uiteraard wordt onderscheid gemaakt tussen de verschillende afstudeerrichtingen, hetgeen binnen de SOI niet wordt gedaan. Daarbij wordt een zesde positie toegevoegd aan de SOI-codes. 
ad. c: De huidige arbeidsmarktsituatie verwijst naar de belangrijkste dagelijkse werkzaamheden die door de respondent worden verricht. Dit om vast te stellen of iemand behoort tot de werkzame beroepsbevolking zoals die door de International Labour Organisation (ILO) wordt gedefinieerd. De hiervoor gestelde vraag is rechtstreeks overgenomen uit de vragenlijst voor de Enquête Beroepsbevolking (EBB) van het CBS (In zoverre dat in de EBB gevraagd wordt of iemand één of meer uren in loondienst werkzaam is. Indien dit het geval is wordt hij of zij gerekend tot de werkzame beroepsbevolking. In onze vragenlijsten wordt gevraagd naar de situatie die de dagelijkse bezigheden het beste weergeeft).

ad. $d$ : In het vragenblok over de kenmerken van beroep en functie wordt gevraagd of men in het afgelopen jaar van functie of werkgever is veranderd, op welke wijze men de huidige functie heeft verkregen, wat de aard en de tijdsduur van de huidige aanstelling is en tot welke (voorgecodeerde) beroepsgroepen men behoort. Ter contrôle hierop is tevens een open vraag opgenomen over de functienaam. De bijgevoegde op de desbetreffende faculteit afgestemde lijst met benamingen van de beroepsgroepen met de bijbehorende codes is afgeleid uit de beroepenclassificatie die door het CBS wordt gehanteerd. Tot dit vragenblok behoren tevens vragen over de mate waarin men leiding moet geven en de hoogte van het bruto maandinkomen.

ad. e: Tot het vragenblok over de kenmerken van de organisatie waarbij men werkzaam is behoren vragen over de branche, de totale personeelsomvang, het soort produkt of dienst van de organisatie en het adres van de vestiging van het bedrijf of de instelling waarbij men werkt. De respondenten wordt gevraagd om de branche-code aan te geven. Hiertoe is voor iedere faculteit een op de desbetreffende faculteit afgestemde lijst van bedrijfsgroepen opgesteld met de bijbehorende SBI-codes (Standaard BedrijfsIndeling) die door het CBS worden gehanteerd. De open vraag over het vestigingsadres wordt gesteld met het oog op het opbouwen van een adressenbestand van werkgevers.

ad. $f$ : Aan de afgestudeerden wordt gevraagd of men op zoek is naar betaald werk en of men daar dan binnen twee weken aan zou kunnen beginnen. Deze vragen zijn opgenomen om vast te kunnen stellen of men overeenkomstig de ILO-definitie nog als werkzoekende, en dus behorend tot de beroepsbevolking, kan worden aangemerkt. Bovendien wordt gevraagd of men in het afgelopen jaar een cursus of opleiding heeft gevolgd en zo ja wat de aard en richting daarvan was. 



\section{DE PROEFENQUETE}

\subsection{Het testen van de vragenlijst}

De basisvragenkaart, de jaarkaart en de bijbehorende toelichtingen en aanbiedingsbrieven zijn in juni 1989 getest in een proefenquête onder een twintigtal afgestudeerde gezondheidswetenschappers in het kader van de eerder genoemde pilotstudie. De naar aanleiding van de proefenquête bijgestelde kaarten en de bijbehorende toelichtingen zijn besproken in de begeleidingscommissie van het project 'follow-up onderzoek afgestudeerden RL' en vervolgens opnieuw bijgesteld. Van de bij de kaarten behorende faculteitspecifieke overzichten van branche- en beroepsgroepen zijn vervolgens versies opgesteld met betrekking tot de FdG, FdR en FdEW. Deze overzichten zijn voor commentaar voorgelegd aan de desbetreffende facultaire leden van de begeleidingscommissie en bijgesteld. De bijgestelde basisvragenkaart en jaarkaart zijn respectievelijk als Bijlage $I$ en III in dit werkdocument opgenomen. Als voorbeeld zijn de versies met betrekking tot de FdEW gekozen. In het najaar van 1989 zijn déze basisvragenkaart en de bijbehorende faculteitspecifieke toelichtingen getest in een proefenquête onder een aantal afgestudeerden van de FdG, FdR en FdEW.

De proefenquête had tot doel:

- nagaan hoe de respons kan worden gemaximaliseerd;

- nagaan of de ontwikkelde basisvragenkaart bijstelling behoeft en of de gebruikte overzichten van branche- en beroepsgroepen voor de respondenten werkbaar zijn;

- testen van het in dBASE aangemaakte data-entryprogramma en het op basis hiervan creëren van een SPSS-systemfile ten behoeve van de analyse.

\subsection{Respons en rappellering}

Van de dienst Studentenzaken (SZ) zijn de in paragraaf 2.2. genoemde persoons- en opleidingsgegevens verkregen van 59 studenten die in de tweede helft van 1988 zijn afgestudeerd. Het betreft alle destijds afgestudeerde economen (19 in totali), 20 aselect gekozen juristen en eveneens 20 aselect gekozen basisartsen. Aangezien er reeds een proefenquête had plaatsgevonden onder een aantal afgestudeerden van de FdGW in het kader van de eerder genoemde pilotstudie zijn afgestudeerde gezondheidswetenschappers in de onderhavige proefenquête niet meegenomen. In oktober 1989 werd aan ieder van 
deze 59 afgestudeerden een basisvragenkaart met de bijbehorende faculteitspecifieke toelichting gezonden. Op de kaart waren de persoons- en opleidingsgegevens reeds voorgedrukt aan de hand van gegevens uit het bestand van de dienst SZ. De basisvragenkaart en bijbehorende toelichting waren vergezeld van een aanbiedingsbrief en een retourenveloppe waarmee de oud-studenten de ingevulde kaart port-vrij konden retourneren. Deze mailing was gericht aan het ouderlijk adres.

De stand van zaken na vier weken was als volgt:

- 32 kaarten ingevuld retour ontvangen (respons van 54\%);

- 3 kaarten oningevuld retour ontvangen vanwege "adres onbekend".

$\mathrm{Na}$ telefonische recherche kon al vlug 1 onbekend adres worden achterhaald. Besloten werd tot een tweede mailing naar de 25 oud-studenten die tot dan nog niet hadden gereageerd en waarvan niet bekend was of het ouderlijk adres al dan niet was gewijzigd. De tweede mailing resulteerde binnen twee weken in de retourontvangst van 8 ingevulde kaarten. Daarmee bedroeg de respons na zes weken $68 \%$ (40 ingevulde kaarten). Van 19 oud-studenten (32\%) was zes weken na de eerste mailing nog geen ingevulde kaart ontvangen, hetzij omdat zij niet wilden meewerken aan het onderzoek, hetzij omdat zij de kaart nooit hadden ontvangen vanwege een gewijzigd adres. Van 2 oud-studenten was bekend dat het ouderlijk adres was gewijzigd. Besloten werd om door middel van telefonische recherche:

- na te gaan of het adres was gewijzigd en indien dit het geval was het actuele adres te achterhalen om vervolgens de basisvragenkaart alsnog toe te sturen (met behulp van telefoonboeken en bevolkingsadministraties van gemeenten kon een aantal gewijzigde adressen worden achterhaald);

- oud-studenten, waarvan het adres bekend was, te bewegen alsnog hun medewerking aan het onderzoek te verlenen.

Het verrichten van bovengenoemde aktiviteiten resulteerde uiteindelijk in 50 retour ontvangen ingevulde vragenlijsten (respons $85 \%$ ).

De respons is als volgt over de faculteiten verdeeld:

- 17 basisartsen (respons 89\%);

- 14 juristen (respons 70\%);

- 19 economen (respons 100\%).

$\mathrm{Na}$ contrôle van de ingevulde gegevens en na codering van de open vragen zijn de aldus verzamelde gegevens in dBASE ingevoerd. De contrôle van de door de 
respondenten ingevulde codenummers betrof in het bijzonder de vragen betreffende het beroep en de branche. Daartoe zijn de door de respondenten gekozen branche- en beroepencode vergeleken met de door hen opgegeven belangrijkste dienst/produkt respectievelijk functienaam. Codering van de functienaam door de onderzoeker leidde in veertien gevallen (28\%) tot een andere beroepencode dan door de respondent was gekozen. Het ging hierbij overwegend om administratieve functies. Met de keuze van de branchecode door de respondenten deden zich beduidend minder problemen voor (bij $10 \%$ van de respondenten). Op dié punten waar problemen zich hebben voorgedaan zijn de lijsten van beroepsgroepen en van branches bijgesteld. Een contrôle op de door de respondent gekozen codering dient dus in alle gevallen plaats te vinden. Overigens wordt dit wel aanzienlijk vereenvoudigd met de door de respondent gekozen codering als uitgangspunt. De open vragen hebben allen betrekking op de aan de RL gevolgde opleiding(en). Deze zijn gecodeerd volgens de SOI van het CBS. Om de afstudeerrichting te kunnen coderen is de SOI uitgebreid met één positie.

Van de ingevoerde gegevens zijn twee bestanden in dBASE aangemaakt: een bestand met de administratieve gegevens en een bestand met de onderzoeksdata. Het administratieve bestand omvat de gegevens die nodig zijn om het verzamelen van de gegevens te kunnen verrichten, namelijk de naam en de voorletters alsmede het geactualiseerde adres (straatnaam, huisnummer, postcode, woonplaats, land) en telefoonnummer van de respondenten. Ook de naam en het adres van de werkgever zijn in het administratieve bestand opgenomen. Het onderzoeksbestand omvat de data die voor de analyse nodig zijn. Hiertoe behoort ook een aantal gegevens die (op het moment van afstuderen) onveranderlijk zijn (geworden) zoals geboortejaar, geslacht, vooropleiding, de reeds aanwezige werkervaring op het moment van afstuderen, de aan de RL gevolgde studie- en afstudeerrichting(en) en de data van aanvang en voltooiing van de studie. De sleutel tussen het administratieve bestand en het bestand met de onderzoeksdata wordt gevormd door het unieke studentnummer van de respondenten.

Het in dBASE aangemaakte bestand met onderzoeksdata is omgezet in een ASCIIbestand teneinde verwerking met behulp van SPSS/PC+ mogelijk te maken. 



\section{PRESENTATIE VAN DE ONDERZOEKSRESULTATEN}

\subsection{Inleiding}

In dit hoofdstuk zal een indruk worden gegeven van de soort onderzoeksresultaten die met behulp van een eerste jaarlijkse bevraging kunnen worden gegenereerd. Aangezien het hierbij gaat om de resultaten van een beperkte proefenquête wordt niet alle mogelijke informatie gepresenteerd maar wordt volstaan met een beperkte selectie die bovendien slechts exemplarische waarde heeft. Met name wanneer er vergelijkingen worden gemaakt tussen de drie in het proefonderzoek betrokken faculteiten is dit slechts als illustratief bedoeld van de soort conclusies die men uit een meer grootschalig onderzoek zou kunnen trekken. De volgende informatie komt in dit werkdocument niet aan bod:

- persoonsgegevens (geboortejaar en geslacht) en studiegegevens (vooropleiding, afstudeerrichting, studieduur en eventuele eerder gevolgde studieen afstudeerrichting) die toch al bij de dienst SZ bekend zijn;

- eventuele werkervaring vóor of tijdens de studie aan de RL;

- bezigheden per maand tussen het moment van afstuderen en de enquêtering;

- de gehanteerde methoden bij het eventuele zoeken naar een (andere) baan ten tijde van de enquêtering;

- de namen van de opleidingen en cursussen die na het behalen van het doctoraal/basisartsexamen worden gevolgd;

- het geactualiseerde adressenbestand van de afgestudeerden en van hun werkgevers.

We1 wordt ingegaan op de huidige positie op de arbeidsmarkt van de onderzochte respondenten, enkele kenmerken van de organisaties waarin men werkt en van de functies die men uitoefent, enkele aspecten van de arbeidsovereenkomst, eventueel gevolgd onderwijs na het afstuderen en de belangstelling voor aktiviteiten die door de RL zouden kunnen worden georganiseerd.

\subsection{Deelname aan het arbeidsproces}

In deze paragraaf wordt inzicht gegeven in de mate waarin de in de proefenquête onderzochte afgestudeerden van de RL deelnemen aan het arbeidsproces en op welke wijze zij hun functies verwerven. Vervolgens komen enkele aspecten van de aanstelling, zoals de aard van het dienstverband en deeltijdwerk, aan bod. 


\subsubsection{Arbeidsssituat_tie}

Aan de respondenten is gevraagd welke situatie het beste past bij hun dagelijkse bezigheden op het moment van de dataverzameling. De resultaten staan vermeld in tabel 1. Hieruit komt naar voren dat de overgrote meerderheid er in is geslaagd om betaald werk te vinden. Afgestudeerden van de FdG en de FdEW zijn hierin beter geslaagd dan afgestudeerde juristen. De werkloosheid, dat wil zeggen het aandeel dat geen betaald werk heeft en op zoek is naar betaald werk, bedraagt $4 \%$.

Tabel 1. De respondenten naar situatie op de arbeidsmarkt op het moment van enquêtering (in \%)

\begin{tabular}{|c|c|c|c|c|}
\hline \multirow[b]{2}{*}{ Situatie } & \multicolumn{3}{|c|}{ Afgestudeerden van de } & \multirow[b]{2}{*}{ Totaal } \\
\hline & FdG & $\mathrm{FdR}$ & FdEW & \\
\hline Betaald werk verrichtend & 94 & 64 & 100 & 88 \\
\hline In militaire dienst & 6 & 7 & -- & 4 \\
\hline Studerend & -- & 7 & -- & 2 \\
\hline Het huishouden verzorgend & -- & -- & -- & -- \\
\hline Arbeidsongeschikt & -- & -- & -- & -- \\
\hline $\begin{array}{l}\text { Onbetaald werk verrichtend } \\
\text { met behoud van uitkering }\end{array}$ & -- & -- & -- & -- \\
\hline Werkloos & -- & 14 & -- & 4 \\
\hline Andere situatie & -- & 7 & -- & 2 \\
\hline Totaal $\mathrm{n}(=100 \%)$ & 17 & 14 & 19 & 50 \\
\hline
\end{tabular}

Alle in de proefenquête onderzochte afgestudeerden die betaald werk verrichten zijn in loondienst werkzaam. Niemand werkt als zelfstandige voor eigen rekening of risico (in een eigen bedrijf of praktijk).

Van alle afgestudeerden is 34\% op zoek naar een (andere) baan: $35 \%$ van de basisartsen, $57 \%$ van de juristen en $16 \%$ van de economen. Behalve werkzoekende werklozen zijn ook onder degenen met een betaalde baan mensen die op zoek zijn naar een andere baan, bijvoorbeeld omdat zij een tijdelijk dienstverband hebben. Van alle afgestudeerden die betaald werk verrichten is $30 \%$ op zoek naar een andere baan (38\% van de betaald werkende basisartsen, $44 \%$ van de betaald werkende juristen en $16 \%$ van de betaald werkende economen). Afgestudeerden met een vaste aanstelling zijn minder vaak op zoek 
naar een andere baan dan degenen met een tijdelijk dienstverband. Van degenen met een vaste aanstelling is $22 \%$ op zoek naar een andere baan; bij degenen met een tijdelijke baan bedraagt het percentage 42 .

\subsubsection{Mobilititeit}

Onder mobiliteit wordt hier verstaan verandering van functie. Hierbij kan een onderscheid worden gemaakt tussen:

- externe mobiliteit, dit wil zeggen verandering van werkgever of werkorganisatie;

- interne mobiliteit, dit wil zeggen verandering van functie bij dezelfde werkgever, bijvoorbeeld promotie, overplaatsing of verandering van functie-inhoud.

Aan de respondenten die op het moment van enquêtering betaald werk verrichten is gevraagd of zij sedert het verlaten van de RL van werkgever zijn veranderd. Dit om vast te stellen of zij op het peilmoment nog steeds in hun intrede-baan (eerste baan na beëindiging van het initiële onderwijs) werkzaam zijn. Op het moment van enquêtering is $75 \%$ van de dan betaald werkende respondenten nog steeds in de intrede-baan werkzaam. Dit wil zeggen dat de externe mobiliteit $25 \%$ bedraagt (een kwart van de betaald werkenden is circa één jaar na het verlaten van de RL reeds van werkgever veranderd). Van de betaald werkende basisartsen is $56 \%$ bij de eerste werkgever werkzaam; bij de juristen bedraagt het percentage 78 en bij de economen 89 .

Aan de respondenten die op het moment van de dataverzameling betaald werk verrichten is niet alleen gevraagd of zij sedert het verlaten van de RL van werkgever zijn veranderd maar ook of zij van functie zijn veranderd. Circa één jaar na het verlaten van de $\mathrm{RL}$ is de interne mobilieit nog gering: slechts $7 \%$ van de dan betaald werkende respondenten is bij dezelfde werkgever van functie veranderd ( $11 \%$ van de basisartsen, $22 \%$ van de juristen en niemand van de economen).

\subsubsection{Functieverwerving}

Aan de afgestudeerden is gevraagd op welke manier zij de huidige functie hebben verkregen. Zij konden één van de voorgedrukte antwoordmogelijkheden kiezen. De resultaten staan vermeld in tabel 2. Bijna $40 \%$ van de afge- 
studeerden heeft de functie die zij op het moment van enquêtering vervulde verkregen door het solliciteren naar aanleiding van een vacature-advertentie. Deze manier van solliciteren is, evenals het open solliciteren, de meest belangrijke geweest. Deze bevinding geldt voor afgestudeerden van alle faculteiten.

Tabel 2. De respondenten naar wijze van functieverwerving betreffende de functie op het moment van enquêtering (in \%); één antwoord mogelijk

\begin{tabular}{lcccc}
\hline & \multicolumn{3}{c}{ Afgestudeerden van de } \\
Functieverwerving & FdG & FdR & FdEW & Totaal \\
\hline Reageren op advertentie & 31 & 56 & 37 & 39 \\
Familie & 6 & -- & -- & 2 \\
Medewerkers RL & -- & -- & 5 & 2 \\
Stage-contacten & 6 & 11 & 5 & 7 \\
Gewestelijk Arbeidsbureau & -- & -- & 5 & 2 \\
Uitzendbureau & 13 & -- & -- & 5 \\
Open sollicitatie & 31 & 22 & 37 & 32 \\
Benaderd door werkgever & 13 & 11 & 11 & 11 \\
Totaal n (=100\%) & 16 & 9 & 19 & 44 \\
\hline
\end{tabular}

\subsubsection{Dienstvererband}

De aard van het dienstverband waarin de onderzochte afgestudeerden werken is weergegeven in tabel 3. De afgestudeerden met een aanstelling van meer dan vijf jaar worden hierbij geacht een vast dienstverband te hebben.

Tabel 3. De respondenten die op het moment van enquêtering betaald werk verrichten naar tijdsduur van de aanstelling (in \%)

\begin{tabular}{lcccc}
\hline & \multicolumn{3}{c}{ Afgestudeerden van de } \\
Tijdsduur aanstelling & FdG & FdR & FdEW & Totaal \\
\hline$<13$ maanden & 38 & 11 & 21 & 25 \\
$13-24$ maanden & 19 & 44 & 5 & 18 \\
$25-60$ maanden & 19 & 11 & 16 & 16 \\
vast di enstverband & 25 & 33 & 58 & 41 \\
Totaal n $(=100 \%)$ & 16 & 9 & 19 & 44 \\
\hline
\end{tabular}


Uit tabel 3 blijkt dat de meerderheid een tijdelijke aanstelling heeft. Van alle afgestudeerden zijn vooral de economen er in geslaagd om een vaste aanstelling te verkrijgen (58\%).

\subsubsection{Deeltijdfuncties}

Naast het vaste of tijdelijke karakter is de lengte van de werkweek een aspect van de aanstelling. De volgende tabel geeft een overzicht van de arbeidstijd van de afgestudeerden.

Tabel 4. De respondenten die op het moment van enquêtering betaald werk verrichten naar arbeidsuren (in \%)

\begin{tabular}{lrrrr}
\hline & \multicolumn{4}{c}{ Afgestudeerden van de } \\
Arbeidsuren & FdG & FdR & FdEW & Totaal \\
\hline$<31$ & 6 & 11 & -- & 5 \\
$31-35$ & 19 & 11 & 16 & 14 \\
$36-39$ & 6 & 33 & 11 & 14 \\
40 & 38 & 44 & 68 & 52 \\
$>40$ & 31 & -- & 5 & 14 \\
Totaal $\mathrm{n}(=100 \%)$ & 16 & 9 & 19 & 44 \\
\hline
\end{tabular}

Eenvijfde deel van de afgestudeerden werkt in deeltijd (maximaal 35 uur per week). De rest heeft een volledige baan, waarin de meesten veertig uur per week werken. Basisartsen hebben relatief lange werkweken.

\subsection{Functiekenmerken}

In deze paragraaf wordt nader ingegaan op de betaalde functies die door de onderzochte afgestudeerden worden vervuld. De functies worden gekarakteriseerd naar de werkorganisatie (omvang en marktsector), de omschrijving van de functie (beroepsgroep) en het niveau van de functie (de mate waarin men leiding moet geven en het inkomen). 


\subsubsection{Grootte van de werkorganisatie}

In de enquête is gevraagd hoeveel mensen er werken in de vestiging van het bedrijf of de instelling waar de respondenten deel van uitmaken. In tabel 5 komt naar voren dat de werkgelegenheid voor academici wordt gedomineerd door grote bedrijven/instellingen.

Tabe1 5. De respondenten die op het moment van enquêtering betaald werk verrichten naar grootte van de werkorganisatie (in \%)

\begin{tabular}{|c|c|c|c|c|}
\hline \multirow[b]{2}{*}{ Aantal personeel sleden } & \multicolumn{3}{|c|}{ Afgestudeerden van de } & \multirow[b]{2}{*}{ Totaal } \\
\hline & FdG & $\mathrm{FdR}$ & FdEW & \\
\hline$<10$ & -- & 11 & -- & 2 \\
\hline $10-49$ & 31 & 44 & 5 & 23 \\
\hline $50-99$ & -- & -- & 11 & 5 \\
\hline$>99$ & 69 & 44 & 84 & 71 \\
\hline Totaal n $(=100 \%)$ & 16 & 9 & 19 & 44 \\
\hline
\end{tabular}

\subsubsection{Marktsectetor}

Hieronder wordt achtereenvolgens voor de drie onderzochte faculteiten nagegaan in welke sector van de arbeidsmarkt hun afgestudeerden terecht zijn gekomen. Onder marktsector wordt verstaan: een op basis van het soort produkt of dienst min of meer homogene groep van werkorganisaties. De benamingen met de bijbehorende coderingen zijn afgeleid uit de Standaard BedrijfsIndeling die door het CBS wordt gehanteerd.

\section{Basisartsen}

In tabel 6 komt naar voren dat de overgrote meerderheid van de onderzochte basisartsen werkzaam is in de niet-zakelijke, medische-dienstverlenende sector; met name in ziekenhuizen. 
Tabel 6. Basisartsen die op het moment van enquêtering betaald werk verrichten naar bedrijfsgroep (in \%)

Bedrijfsgroep

Industrie

12

Wettelijke sociale verzekeringsorganen, ziekenfondsen

6

Hoger beroepsonderwijs

6

Overig onderwijs

6

Algemene en gespecialiseerde ziekenhuizen (excl. psychiatrische)

Psychiatrische inrichtingen/klinieken

Overige medische-dienstverlenende instellingen

Research- e.d. en wetenschappelijke instellingen

Totaal n $(=100 \%)$

\section{Juristen}

De meeste juristen oefenen hun werkzaamheden in overheidsdienst uit. Hiermee verschillen zij van de economen die vooral in de zakelijke dienstverlenende sektor werkzaam zijn.

Tabel 7. Juristen die op het moment van enquêtering betaald werk verrichten naar bedrijfsgroep (in \%)

Bedrijfsgroep

Rechtskundige diensten

Accountants-, boekhoudbureaus, belastingconsulenten

Algemene overheidsadministraties

Defensie

Wettelijke sociale verzekeringsorganen, ziekenfondsen

Wetenschappelijk onderwijs

Publ iekrechtelijke bedrijfsorganen

Werknemersorganisaties

Totaal n $(=100 \%)$ 


\section{Economen}

In tabel 8 komt naar voren dat de meeste economen werkzaam zijn in de dienstverlenende sektor (met name de zakelijke dienstverlening op economisch gebied) en in het wo. Slechts een kwart van de economen werkt in de bedrijfstak 'industrie'. De economen die in overheidsdienst zijn werken allen in het onderwijs.

Tabel 8. Economen die op het moment van enquêtering betaald werk verrichten naar bedrijfsgroep (in \%)

Economische aktiviteit

\begin{tabular}{ll}
\hline Industrie & 26
\end{tabular}

Bankwezen $\quad 5$

Accountantsbureaus $\quad 26$

Bedrijfsecomische en organisatorische adviesbureaus $\quad 11$

Sociale verzekeringsorganen, ziekenfondsen $\quad 5$

Hoger beroepsonderwijs $\quad 5$

Wetenschappelijk onderwijs $\quad 21$

$\begin{array}{ll}\text { Totaal } \mathrm{n}(=100 \%) & 19\end{array}$

\subsubsection{Beroep}

Hieronder wordt achtereenvolgens voor de drie onderzochte faculteiten nagegaan welke beroepen door hun afgestudeerden worden uitgeoefend. Daarbij wordt nagegaan of het beroep aansluit bij de gevolgde studierichting. De benamingen van de beroepsgroepen met de bijbehorende coderingen zijn afgeleid uit de beroepenclassificatie die door het CBS wordt gehanteerd.

\section{Basisartsen}

Vrijwel alle basisartsen verrichten betaald werk. In tabel 9 komt naar voren dat de meerderheid van de geënquêteerde basisartsen een medische functie uitoefent; de meesten als arts-assistent in een ziekenhuis. 
Tabel 9. Basisartsen die op het moment van enquêtering betaald werk verrichten naar beroep(sgroep), in \%

Beroep(sgroep)

Arts-assistent in ziekenhuis

44

School-, bedrijfs-, consultatiebureau-, verzekeringsarts (geen specialist)

13

Sociaal-geneeskundige

Overige (para)medische en verwante functies

13

Docent

13

Bedrijfsleider, algemene leiding

6

Bedrijfsleider, produktie

6

Totaal $\mathrm{n}(=100 \%)$

16

\section{Economen}

Zoals eerder is gebleken zijn alle geënquêteerde economen er in geslaagd om een betaalde baan te vinden. Uit tabel 10 komt naar voren dat de meeste economen bovendien terecht zijn gekomen in 'economische' beroependomeinen.

Tabel 10. Economen die op het moment van enquêtering betaald werk verrichten naar beroep(sgroep), in \%

Beroep(sgroep)

Bedrijfsorganisatiedeskundige

Economist, (bedrijfs)econoom, sociaal-economisch onderzoeker

Marketing specialist

Docent

Hogere leidinggevende functie

Boekhouder

Assistent-accountant

Hogere/middelbare bankemployé

Administratieve functie n.e.g.

Totaal n $(=100 \%)$ 
Juristen

Zoals eerder is gemeld hebben negen van de in totaal veertien onderzochte juristen op het moment van de dataverzameling betaald werk. Van deze negen juristen zijn acht werkzaam als juridisch medewerker; één oefent het beroep van leraar uit.

\subsubsection{Leidingggeven}

Aan de respondenten is de vraag voorgelegd aan hoeveel personen leiding moet worden gegeven bij de uitoefening van de functie. Hiervan geeft tabel 11 een beeld. In de tabel komt naar voren dat circa $70 \%$ geen leidinggevende functie uitoefent; eenvijfde deel van de respondenten geeft leiding aan maximaal vier personen. Deze resultaten zijn niet verwonderlijk aangezien het gaat om academici die pas één jaar zijn afgestudeerd en die bijgevolg staan aan het begin van hun beroepscarrière. Overigens zijn de onderzochte juristen iets minder vaak in leidinggevende functies werkzaam dan basisartsen en economen.

Tabel 11. De respondenten die op het moment van enquêtering betaald werk verrichten naar mate van leidinggeven (in \%)

\begin{tabular}{llcrr}
\hline & \multicolumn{4}{c}{ Afgestudeerden van de } \\
$\begin{array}{l}\text { Aantal personen waaraan } \\
\text { leiding wordt gegeven }\end{array}$ & FdG & FdR & FdEW & Totaal \\
\hline Geen & & & & \\
$1-4$ & 63 & 89 & 68 & 71 \\
$5-9$ & 25 & 11 & 16 & 18 \\
$>9$ & 13 & -- & 5 & 7 \\
Totaal $n(=100 \%)$ & -- & -- & 11 & 5 \\
\hline
\end{tabular}

\subsubsection{Inkomen}

Naast de mate warin men leiding geeft vormt ook het inkomen een indicatie voor het niveau van de functie. Het inkomen is tevens wellicht afhankelijk van de marktsector. Bij het onderzoek zijn gegevens verkregen omtrent het 
bruto-inkomen per maand bij een volledige werkweek (exclusief toeslagen voor overwerk, dertiende maand, vakantiegeld en dergelijke). De bruto maandinkomens staan vermeld in tabel 12.

Tabel 12. De respondenten die op het moment van enquêtering betaald werk verrichten naar bruto-maandinkomen bij een volledige werkweek (in \%)

\begin{tabular}{lcccc}
\hline & \multicolumn{3}{c}{ Afgestudeerden van de } \\
Bruto-maandinkomen & FdG & FdR & FdEW & Totaal \\
\hline Onbekend & -- & 11 & 5 & 5 \\
< 2500 & -- & -- & 16 & 7 \\
$\mathrm{f} 2500-3000$ & 6 & -- & -- & 2 \\
$\mathrm{f} 3000-3750$ & 31 & 78 & 47 & 48 \\
$\mathrm{f} 3750-5000$ & 50 & 11 & 26 & 32 \\
$>\mathrm{f} 5000$ & 13 & -- & 5 & 7 \\
Totaal $n(=100 \%)$ & 16 & 9 & 19 & 44 \\
\hline
\end{tabular}

Circa één jaar na het afstuderen verdient ongeveer de helft van de afgestudeerden $f 3000$ - 3750 bruto per maand; circa eenderde deel verdient $f 3750-$ 5000 bruto per maand. Uitschieters naar boven en naar beneden zijn uitzonderingen. Basisartsen behoren tot de relatief hogere inkomensgroepen. Zij zijn ook relatief vaker in leidinggevende functies werkzaam.

\subsection{Aanvullende opleidingen}

Aan de respondenten is gevraagd of $z i j$ na het behalen van het doctoraal/basisartsexamen nog verder onderwijs volgen of hebben gevolgd. De aard en de richting van het vervolgonderwijs komen achtereenvolgens in tabel 13 en 14 aan bod.

Tabel 13 geeft een beeld van de aard van de opleidingen die door de respondenten na het afstuderen worden (zijn) gevolgd. Het gaat hierbij om het niveau van de opleiding in combinatie met het voltijd/deeltijdkarakter van de opleiding. 
Tabel 13. De respondenten naar aard van de opleiding na afstuderen (in \%)

\begin{tabular}{|c|c|c|c|c|}
\hline \multirow[b]{2}{*}{ Aard van de opleiding } & \multicolumn{3}{|c|}{ Afgestudeerden van de } & \multirow[b]{2}{*}{ Totaa } \\
\hline & $\mathrm{FdG}$ & $\mathrm{FdR}$ & FdEW & \\
\hline wo, voltijd & -- & 14 & 21 & 12 \\
\hline Wo, deeltijd & 18 & 7 & 32 & 20 \\
\hline Andere opleiding & 18 & 21 & 11 & 16 \\
\hline Geen opleiding & 65 & 57 & 37 & 52 \\
\hline Totaal $n(=100 \%)$ & 17 & 14 & 19 & 50 \\
\hline
\end{tabular}

De helft van de respondenten heeft in de twaalf maanden na het behalen aan de RL van het afsluitende examen geen vervolgopleiding- of cursus meer gevolgd. Van degenen die wel vervolgonderwijs volgen (hebben gevolgd) heeft de meerderheid gekozen voor wo; doorgaans in deeltijd.

In tabel 14 komt naar voren dat de meeste vervolgopleidingen- en cursussen, wat de richting betreft, een aanvulling vormen op of in het verlengde liggen van het aan de RL gevolgde curriculum.

Tabel 14. De respondenten naar richting van de opleiding na afstuderen (in \%)

\begin{tabular}{lcccc}
\hline & \multicolumn{3}{c}{ Afgestudeerden van de } \\
Richting van de opleiding & FdG & FdR & FdEW & Totaal \\
\hline Wiskunde, natuurwetenschappen & 6 & -- & -- & 2 \\
Medisch, paramedisch & 18 & -- & -- & 6 \\
Economisch, administratief, commercieel & -- & -- & 58 & 22 \\
Juridisch, bestuurlijk & -- & 21 & -- & 6 \\
Andere opleidingsrichting & 12 & 21 & 5 & 12 \\
Geen opleiding & 65 & 57 & 37 & 52 \\
Totaal n (=100\%) & 17 & 14 & 19 & 50 \\
\hline
\end{tabular}




\subsection{Aktiviteiten voor afgestudeerden}

Aan de respondenten is een aantal aktiviteiten voorgelegd die voor afgestudeerden van de RL zouden kunnen worden georganiseerd. De respondenten konden aangeven of zij belangstelling hebben voor deze aktiviteiten. De belangstellingscore is als volgt. Slechts $10 \%$ van de afgestudeerden geeft te kennen in geen enkele aktiviteit geïnteresseerd te zijn. De grootste belangstelling blijkt te bestaan voor reünies, een magazine voor oud-studenten en een adressenlijst van oud-studenten. Voor matregelen ter bevordering van de plaatsing op de arbeidsmarkt van afgestudeerden bestaat minder belangstelling. Dit zal wellicht verband houden met het feit dat de meerderheid van de respondenten op het moment van de enquêtering al een betaalde baan heeft weten te vinden waardoor de behoefte aan dergelijke maatregelen is komen te vervallen. Van alle afgestudeerden hebben de juristen nog de meeste belangstelling voor plaatsingsbevorderende matregelen. Zoals in paragraaf 4.2.1. naar voren is gekomen zijn juristen dan ook minder dan basisartsen en economen er in geslaagd om betaald werk te vinden en vaker op zoek naar een (andere) betaalde baan.

Tabel 15. Belangstelling voor aktiviteiten met betrekking tot afgestudeerden (in $\%$ van de totale populatie); meer antwoorden mogelijk

Aktiviteiten

\begin{tabular}{|c|c|c|c|c|}
\hline & FdG & $\mathrm{FdR}$ & FdEW & Totaal \\
\hline Reünie van jaar- en/of studiegenoten & 71 & 79 & 68 & 72 \\
\hline Tijdschrift voor afgestudeerden & 71 & 71 & 68 & 70 \\
\hline $\begin{array}{l}\text { Notatie in jaarlijkse adressenlijst voor } \\
\text { afgestudeerden van de desbetreffende faculteit }\end{array}$ & 53 & 64 & 74 & 64 \\
\hline $\begin{array}{l}\text { Themadag voor afgestudeerden van de } \\
\text { desbetreffende faculteit }\end{array}$ & 53 & 57 & 74 & 62 \\
\hline $\begin{array}{l}\text { Voorlichting geven aan studenten in de desbe- } \\
\text { treffende faculteit over praktijk na afstuderen }\end{array}$ & 41 & 14 & 37 & 32 \\
\hline Opname in sollicitantenbank & 24 & 43 & 5 & 22 \\
\hline Vacaturebank & 24 & 21 & 16 & 20 \\
\hline Deelname aan sollicitatiecursus & 18 & 29 & 5 & 16 \\
\hline Geen aktiviteit & 6 & 7 & 16 & 10 \\
\hline
\end{tabular}

$\%$ dat belangstelling heeft 



\section{BEVINDINGEN}

\subsection{Dataverzameling en -verwerking}

De aanpak waarbij de afgestudeerden één jaar na het verlaten van de RL voor een follow-up onderzoek op hun ouderlijk adres schriftelijk worden benaderd heeft tezamen met schriftelijke en telefonische rappellering geleid tot een respons van $85 \%$ (bij de medici en economen zelfs van respectievelijk $89 \%$ en $100 \%$ ). De respons bij de juristen is het laagst $(70 \%)$. Bij de non-responderende juristen zijn echter drie afgestudeerden waarvan bekend is dat hun adres is gewijzigd. De actuele adressen zijn inmiddels bij de desbetreffende gemeenten aangevraagd. De respons bij de juristen kan derhalve nog iets hoger uitvallen. Overigens bestaat de populatie die wel heeft gereageerd niet alleen uit afgestudeerden die er in zijn geslaagd om betaald werk te vinden.

De verzamelde gegevens zijn waar nodig (opnieuw) gecodeerd. Hercodering door de onderzoeker was in een aantal gevallen nodig bij de vragen naar de beroepen- en de branchecode. De faculteitspecifieke overzichten van branches en beroepen zijn waar nodig bijgesteld. Vervolgens zijn de gegevens in dBASE ingevoerd tot een administratief bestand en een bestand met onderzoeksdata. Het in dBASE aangemaakte onderzoeksbestand is vervolgens omgezet in een voor statistische analyse geschikt bestand. Bij deze stappen in het proefonderzoek hebben zich geen noemenswaardige problemen voorgedaan.

\subsection{Bijstelling van de basisvragenkaart}

Naar aanleiding van de proefenquête is besloten om een aantal vragen van de basisvragenkaart bij te stellen. De reden voor bijstelling was doorgaans gelegen in het feit dat deze vragen niet consistent werden beantwoord. De belangrijkste bijstellingen hadden betrekking op de volgende vragen van de basisvragenkaart, die als Bijlage I is opgenomen:

- vraag 13 betreffende de aan de RL gevolgde studie- en afstudeerrichting(en);

- vraag 15 betreffende de maand waarin men aan de RL is afgestudeerd;

- vraag 18 betreffende de bezigheden per maand in de periode tussen de maand van afstuderen en de maand van enquêtering;

- vraag 19 betreffende de verandering van functie;

- vraag 33 betreffende (de methoden bij) het zoeken naar (ander) betaald 
werk op het moment van enquêtering.

\section{Vraag 13: Studie- en afstudeerrichting}

Hierbij doet zich het probleem voor dat twee van de vier studierichtingen aan de RL wel afstudeerrichtingen kennen (gezondheidswetenschappen en economie) en twee studierichtingen niet (geneeskunde en Nederlands recht). Het onderscheid tussen enerzijds 'studierichting' en anderzijds 'afstudeerrichting' is bijgevolg slechts voor een bepald deel van de afgestudeerden relevant, afhankelijk van hun aan de RL gevolgde studierichting. Daarbij is gebleken dat het onderscheid tussen studierichting en afstudeerrichting, zoals dat in de vragenkaart is opgenomen, niet voor alle respondenten duidelijk is. Sommige economen vulden bij afstudeerrichting 'economie' in; andere economen de desbetreffende 'sectie' binnen bedrijfseconomie. Besloten is om deze open vraag te vervangen door een gesloten vraag waarbij de mogelijke afstudeerrichtingen reeds zijn aangegeven en de respondenten de voor hen van toepassing zijnde afstudeerrichting(en) kunnen omcirkelen.

\section{Vraag 15: Maand van afstuderen}

Hierbij doen zich twee problemen voor. In de eerste plaats kan de maand waarin men afstudeert per afgestudeerde verschillen. Daarbij komt dat voor sommige respondenten dit de maand is waarin men zijn of haar studie-activiteiten aan de RL heeft beëindigd terwijl voor anderen dit de maand is waarin men officieel is afgestudeerd. Besloten is om te vragen naar de maand warin men het desbetreffende einddiploma heeft ontvangen.

\section{Vraag 18: Bezigheden per maand}

Aangezien de maand waarin het einddiploma wordt uitgereikt en de maand waarin de basisvragenkaart wordt ingevuld per afgestudeerde kunnen verschillen, is besloten om het aantal voorgedrukte maanden te verdubbelen tot 24 . Aan de respondenten wordt gevraagd om de maand waarin het einddiploma is uitgereikt en de maand waarin de vragenlijst wordt ingevuld te omcirkelen en bij iedere tussenliggende maand het codenummer te noteren dat het beste past bij de dagelijkse bezigheden in de desbetreffende maand. 
Vraag 19: Verandering van functie

Aangezien de primaire functie van deze vraag is te meten of er wel of niet sprake is van interne mobiliteit, is besloten om aan 'verandering van functie' toe te voegen 'bij dezelfde werkgever'. Tevens is besloten om deze vraag uit te breiden met een open vraag naar de belangrijkste reden voor de verandering van de functie. Ook vraag 20 betreffende verandering van werkgever zal worden uitgebreid met een open vraag naar de belangrijkste reden om van werkgever te veranderen.

\section{Vraag 33: Zoekmethoden}

Aangezien de vraag over de wijze van functieverwerving (vraag 21) al een indicatie vormt voor het zoekgedrag op de arbeidsmarkt is besloten om vraag 33 te beperken tot haar primaire functie, namelijk meten of men wel of niet op zoek is naar (ander) betaald werk (en bijgevolg overeenkomstig de ILOdefinitie als werkzoekend, en dus behorend tot de beroepsbevolking, kan worden aangemerkt). Tevens is besloten om deze vraag uit te breiden met een open vraag naar de belangrijkste reden voor het zoeken naar (ander) betaald werk.

Uit de reacties van enkele afgestudeerden bleek dat zij het systeem van een basisvragenkaart, een bijbehorende toelichting op de vragen en een bijlage met daarin opgenomen een overzicht van de op de desbetreffende faculteit afgestemde branche- en beroepsgroepen niet overzichtelijk vonden. Derhalve is besloten om de basisvragenkaart, de toelichting op de vragen en het overzicht van de op de desbetreffende faculteit afgestemde branche- en beroepsgroepen te vervangen door één vragenformulier waarin per vraag de bijbehorende toelichting is opgenomen. Het overzicht van de op de desbetreffende faculteit afgestemde branche- en beroepsgroepen wordt als bijlage toegevoegd. In een dergelijk vragenformulier kunnen ook de bovengenoemde aanpassingen respondentvriendelijk worden opgenomen. Deze naar aanleiding van de proefenquête opgestelde basisvragenlijst is als Bijlage II in dit werkdocument opgenomen.

Overigens zal de jaarkaart, waarmee de oud-studenten jaarlijks eventueel opgetreden mutaties kunnen doorgeven, qua vormgeving niet veranderen. De jaarkaart, waarop de gegevens staan voorgedrukt die in het voorgaande jaar 
door de respondent zijn verstrekt, blijft vergezeld van een aparte toelichting op de vragen en van een bijlage met daarin opgenomen een overzicht van de op de desbetreffende faculteit afgestemde branche- en beroepsgroepen. In deze vorm blijft het karakter van de jaarkaart als een mutatiekaart bewaard. De jaarkaart is als Bijlage III opgenomen in dit werkdocument.

\subsection{Onderzoeksaktiviteiten in 1990}

Nadat de voorgaande hoofdstukken waren opgesteld is van één basisarts die in het buitenland verblijft alsnog een ingevulde basisvragenkaart ontvangen. Bijgevolg is deze respondent niet in de berekening van de tabellen opgenomen. Hiermee bedraagt de respons in mart $199086 \%$ (70\% van de juristen, $90 \%$ van de basisartsen en alle economen). De proefenquête heeft aangetoond dat het mogelijk is om door middel van een schriftelijke enquêtering op het ouderlijk adres (circa één jaar na afstuderen) een alleszins bevredigende respons te bereiken, zelfs wanneer een geactualiseerd adressenbestand in eerste instantie ontbreekt en er op instellingsniveau nog geen contacten bestaan met afgestudeerden (bijvoorbeeld via een magazine). Tevens heeft de proefenquête aangetoond dat met behulp van het ontwikkelde onderzoeksinstrument gedetailleerde gegevens kunnen worden gegenereerd met betrekking tot de deelname aan het arbeidsproces, de functies die door de afgestudeerden worden vervuld en hun deelname aan aanvullende opleidingen. De proefenquête heeft echter ook aanleiding gegeven tot verbetering en aanpassing van het onderzoeksinstrument. De verbeteringen betreffen de in paragraaf 5.2. behandelde vragen. De aanpassing betreft de vormgeving die meer respondentvriendelijk wordt.

Met behulp van de verbeterde en aangepaste basisvragenijist worden in 1990 drie populaties afgestudeerden in drie schriftelijke enquêtes onderzocht:

- In mart van dit jaar worden allen die in de tweede helft van het kalenderjaar 1988 zijn afgestudeerd op hun ouderlijk adres schriftelijk geënquêteerd. Deze populatie wordt dus, afhankelijk van de maand waarin men is afgestudeerd, 15 tot 20 maanden na hun afstuderen voor de eerste keer geënquêteerd. Aangezien de meeste studenten in de maanden juliseptember afstuderen, vindt de enquête bij de meesten 15 tot 17 maanden na het afstuderen plaats. In juni 1990 komen de resultaten van deze enquête beschikbaar.

- Allen die in de kalenderjaren 1986, 1987 of in de eerste helft van 1988 zijn afgestudeerd worden in juni 1990 voor de eerste keer geënquêteerd. 
Deze populatie wordt dus, afhankelijk van het jaar waarin men is afgestudeerd, 2, 3, of 4 jaar na het afstuderen voor de eerste keer geënquêteerd. Ten behoeve van deze populatie zal de vraag naar de bezigheden in de maanden tussen afstuderen en enquêteren in de basisvragenlijst worden aangepast. In oktober komen de resultaten van deze enquête beschikbaar.

- Degenen die in het kalenderjaar 1989 zijn afgestudeerd zullen integraal in september 1990 voor de eerste keer worden geënquêteerd. Deze populatie wordt dus, afhankelijk van de maand waarin men is afgestudeerd, 9 tot 20 maanden na hun afstuderen voor de eerste keer geënquêteerd. Aangezien de meeste studenten in de maanden juli - september afstuderen, vindt de enquête bij de meesten 12 tot 14 maanden na het afstuderen plaats. In december worden de resultaten met betrekking tot de jaargang 1989 gerapporteerd.

Tijdschema onderzoeksaktiviteiten 1990

\begin{tabular}{|c|c|c|c|}
\hline \multirow[t]{2}{*}{ Onderzoeksaktiviteiten } & \multicolumn{3}{|c|}{ Afgestudeerden in de periode } \\
\hline & juli - dec 1988 & 1986 - juni 1988 & 1989 \\
\hline Eerste enquêtering na afstuderen & mrt ' 90 & & \\
\hline Rapportering & juni ' 90 & & \\
\hline Eerste enquêtering na afstuderen & & juni ' 90 & \\
\hline Rapportering & & okt ' 90 & \\
\hline Eerste enquêtering na afstuderen & & & sept \\
\hline Rapportering & & & dec \\
\hline
\end{tabular}

Bij continuering van het onderzoekproject worden de bovengenoemde drie populaties afgestudeerden met ingang van 1991 jaarlijks met behulp van de jaarkaart (waarmee zij eventuele mutaties kunnen doorgeven) integraal geënquêteerd. Het streven is er op gericht om deze jaarlijkse mutatie-enquêtes iedere keer in oktober te houden. In september worden dan degenen die in het desbetreffende vorige kalenderjaar zijn afgestudeerd met behulp van de basisvragenlijst voor de eerste keer geënquêteerd. Op deze wijze komt ieder jaar een geactualiseerd databestand beschikbaar. 



\section{$\underline{\text { LITERATUUR }}$}

Dam, J.W. van, J.A.M. Heijke, G.W.M. Ramaekers (1989), Ontwerp van een arbe idsmarktscanner voor academici, ROA-R-1989/3, Maastricht.

Rijksuniversiteit Limburg (1988), Ontwikkelingsplan 1989-1992 Rijksuniversite it Limburg, Maastricht. 

Beste econoom,

Het is nu al weer ruim een jaar geleden, dat $u$ de Faculteit der Economische Wetenschappen van de Rijksuniversiteit Limburg (RL) heeft verlaten. Wij zijn dan ook geïnteresseerd in de ervaringen die $u$ het afgelopen jaar heeft opgedaan. Bijvoorbeeld of $u$ na uw universitaire opleiding een baan heeft kunnen vinden. Om dit aan de weet te komen vragen wij $u$ om mee te werken aan een periodiek loopbaanonderzoek onder afgestudeerden van de RL.

Door het invullen van de basisvragenkaart draagt $u$ er toe bij dat wij onze opleiding beter kunnen afstemmen op de praktijk. Deze gegevens zijn belangrijk voor jongeren die nog een studiekeuze moeten maken. Onze huidige en toekomstige studenten kunnen dan zien welke richtingen je met economische wetenschappen op kunt.

In dit loopbaanonderzoek werkt de Faculteit der Economische Wetenschappen samen met het Researchcentrum voor Onderwijs en Arbeidsmarkt (ROA) van de RL. De coördinatie van dit onderzoekproject is voorlopig in handen van het ROA. Op termijn zal echter worden gestreefd naar een onafhankelijke stichting. Deze stichting zal de universiteit behulpzaam zijn bij het ontplooien van activiteiten ten behoeve van afgestudeerden aan de RL. Als u wilt deelnemen aan deze activiteiten kunt $u$ dat op de basisvragenkaart aangeven.

De door $u$ op de basisvragenkaart ingevulde gegevens zullen anoniem voor het bovengenoemde loopbaanonderzoek worden gebruikt.

De ingevulde basisvragenkaart kunt $u$ in de bijgevoegde antwoordenveloppe zonder postzegel sturen naar het ROA. Liefst zo snel mogelijk. Over enkele maanden zal een samenvattend verslag van het loopbaanonderzoek verschijnen. Indien $u$ daarvoor belangstelling heeft kunt $u$ dit kenbaar maken op de basisvragenkaart. Meer informatie kunt u krijgen bij dhr. G. Ramaekers, ROA, Postbus 616, 6200 MD Maastricht, telefoon 043 - 888852 .

We hopen dat $u$ mee wilt werken aan dit loopbaanonderzoek. Alvast hartelijke dank en veel succes in de toekomst.

\section{INSTRUCTIES VOOR HET INVULLEN VAN DE VRAGEN}

Lees eerst onderstaande instructies voordat u de vragen gaat beantwoorden!

De enquête bestaat uit een basisvragenkaart en een bijbehorende toelichting op de vragen. Alle antwoorden noteert $u$ alleeén op de basisvragenkaart. Lees bij iedere vraag eerst de bijbehorende toelichting. Noteer daarna het antwoord. Deze toelichting heeft $u$ nodig om te weten welke codenummers u bij het invullen van de basisvragenkaart dient te gebruiken.

Een aantal antwoorden op de basisvragenkaart is reeds voorgedrukt aan de hand van gegevens uit het bestand van de Faculteit der Economische Wetenschappen. Alleen gegevens die niet, onvolledig of onjuist zijn genoteerd, dient u uitsluitend in de daarvoor bestemde hokjes in te vullen. Noteer de antwoorden altijd in blokletters en neem codenummers uit de toelichting bij de vragen nauwkeurig over. De verwerking van de basisvragenkaarten gaat dan veel vlotter.

ALVAST HARTELIJKE DANK VOOR UW MEDEWERKING! 
1. naara:

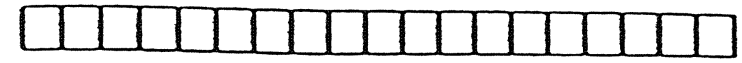

3. stractraam:

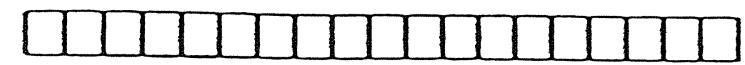

5. woomplats:

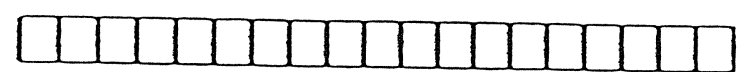

7. land:

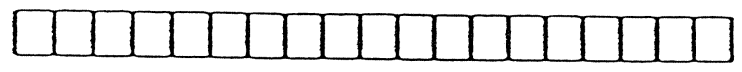

9. goboort jaar: \begin{tabular}{|l|l|l|}
\hline & & \\
\hline
\end{tabular}
2. voorletters:

4. nulsnumer:

6. postcode:

B. telofon:

10. geslactit: $x-1$
पाय

प1口

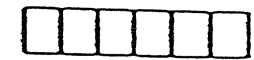

11. vooropleiding: 12. (werk)ervaring: werk: $\square$ assistent: $\square$ overig: $\square$

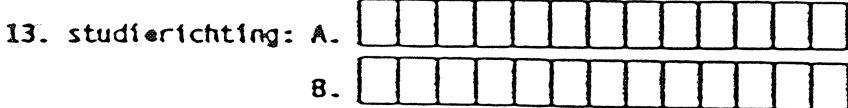

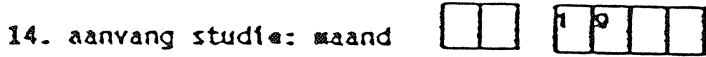

16. huidige situatie:

18. bezigheden oktober $1988 \mathrm{t} / \mathrm{m}$ september 1989:

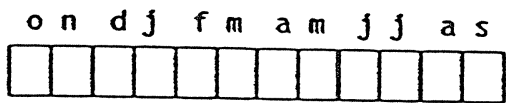

Wet lk vraag hoeft voor u relevant te ziln (zle toelfchting)

19. verznsering functl : $\square$

20. verandering werkgever: $\square$

21. Punctioning:

1

22. dienstverband:

23. tyjdsdur anstaling: $\square$

24. irto fdsuren:

26. functienaar:

25. beropsgrop: $\square$

27. Ielding:

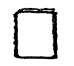

28. Inkomen:

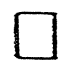

29. branchegroep:

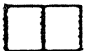

30. naak + wadras:

31. dionst/produkt:

32. person i somvang:

33. zoksthoden:

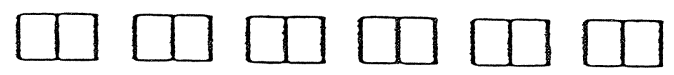

34. beschikbaartidi:

35. opleiding: ard: $\square$ richting: $\square$ naa:

36. dolna extivititan: $\square \square \square \square \square \square \square \square \square \square$ 37. versiag onderzoek: 
ALLEEN DE ANTWOORDEN DIE NIET, ONJUIST OF ONVOLLEDIG ZIJN VOORGEDRUKT INVULLEN! GEBRUIK UITSLUITEND DE DAARVOOR BESTEMDE HOKJES.

Vraag 1: Gehuwde vrouwen dienen hier alleen hun meisjesnaam te vermelden.

Vraag 8: Plaats tussen netnummer en abonneenummer een liggend streepje (-).

Vraag 11: Noteer het codenummer dat uw hoogste vooropleiding voór de RL-studie het beste weergeeft.

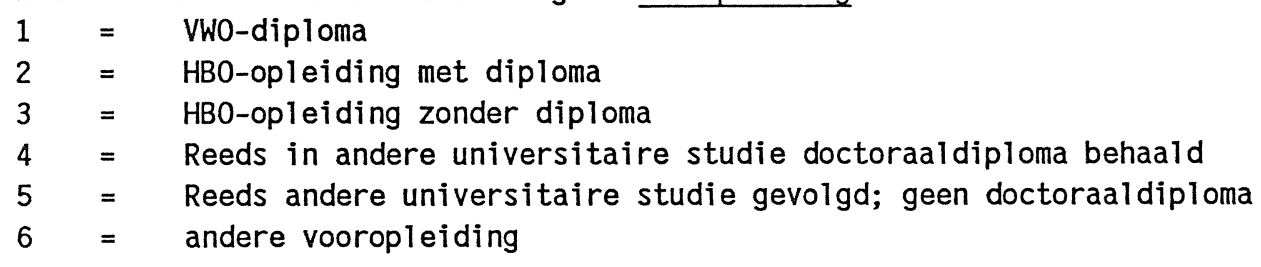

Vraag 12: Vul voor de categorieën werk, assistent en overig het codenummer in, dat het beste past bij uw ervaring voór/tijdens uw studie aan de RL. Indien per categorie meerdere antwoorden van toepasssing zijn, noteer dan het hoogste cijfer.

betaald werk:

$0=$ geen werkervaring/vakantiewerk/weekendwerk

1 = part-time/full-time baan hooguit 1 jaar; op niet-economisch gebied

2 = part-time/full-time baan hooguit 1 jaar; op economisch gebied

3 = part-time/full-time baan langer dan 1 jaar; op niet-economisch gebied

4 = part-time/full-time baan langer dan 1 jaar; op economisch gebied

assistent:

$0=$ geen ervaring als studentassistent

$1=$ wel ervaring als studentassistent

overig:

$0=$ geen of andere dan onderstaande ervaring

1 = bestuurlijke ervaring in studentenvereniging en dergelijke

$2=$ vrijwilligerswerk op niet-economisch gebied

$3=$ vrijwilligerswerk op economisch gebied

Vraag 13: Noteer hier de door $u$ gevolgde universitaire studierichting(en) met bijbehorende afstudeerrichting(en) waarvoor $u$ uw doctoraaldiploma heeft behaald. Indien $u$ naast de bij A voorgedrukte universitaire opleiding nog meer universitaire opleidingen met een doctoraaldiploma heeft afgesloten, noem van deze dan alleen diegene die $u$ het laatste heeft behaald.

Vraag 14: Geef hier maand en jaar aan waarop u met uw studie economie aan de RL bent begonnen.

Vraag 15: Geef hier maand en jaar aan waarop u uw studie economie aan de RL heeft beëindigd.

Vraag 16: Deze vraag betreft uw huidige situatie. Als u onderstaande mogelijkheden bekijkt, waartoe rekent u zich dan? Vul het codenummer in dat het beste past bij uw huidige situatie. U kunt slechts één codenummer invullen.

1 = betaald werk; $u$ heeft een werkkring, bedrijf of praktijk

werkt in loondienst

werkt voor eigen rekening of risico

werkt als gezinslid mee in het bedrijf van echtgenoot/ouders

werkt op een sociale werkplaats

in opleiding bij een bedrijf of instelling maar met loon of salaris

stagiair met loon of salaris

dienstplichtig militair (eerste oefening) of vervangende dienstplicht

$=$ dienstplichtign, student

$=$ huisvrouw/huisman

= gepensioneerd, renteniert, vervroegd pensioen

= arbeidsongeschikt; geheel of gedeeltelijk

= onbetaald werk met behoud van uitkering, vrijwilligerswerk

$=$ werkloos

$=$ andere situatie 
Bij codenummer 1 gaat $u$ na het beantwoorden van vraag 17 en 18 verder met vraag 19; indien u meer dan één baan heeft, hebben de vragen 19 tot en met 32 alleen betrekking op de baan met de meeste arbeidsuren.

$B i j$ de overige codenummers gaat $u$ na het beantwoorden van vraag 17 en 18 verder met vraag 33 .

Vraag 17: Bent u op zoek naar een (andere) baan voor uzelf?

$\begin{array}{lll}1 & = & \text { ja } \\ 2 & = & \text { nee }\end{array}$

Vraag 18: Noteer voor iedere maand in de periode oktober $1988 \mathrm{t} / \mathrm{m}$ september 1989 het codenummer dat het beste past bij de dagelijkse bezigheden die $u$ toen had.

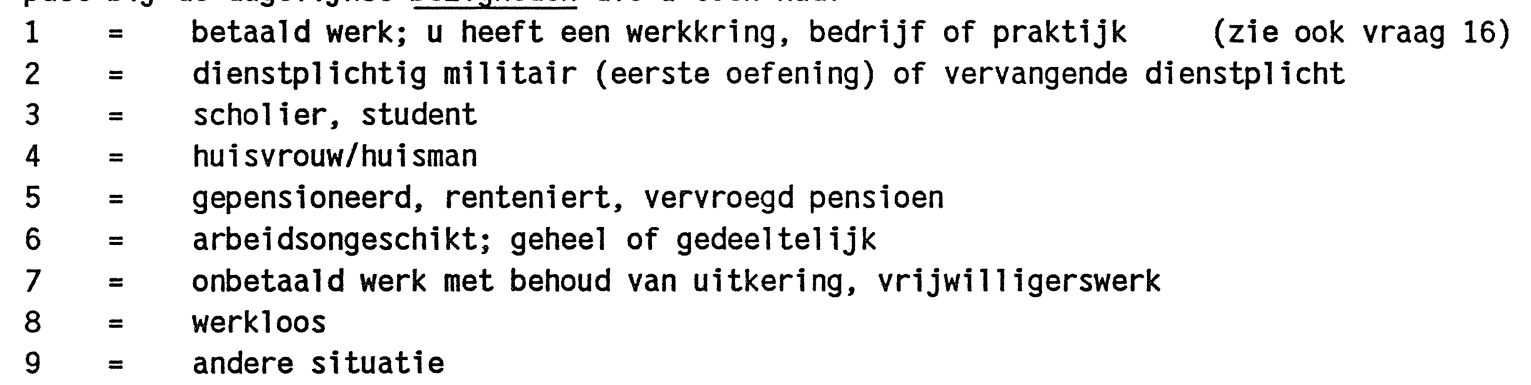

Vraag 19: Bent $u$ in de afgelopen 12 maanden van functie veranderd?

$$
\begin{aligned}
& 1=\text { ja } \\
& 2=\text { nee }
\end{aligned}
$$

Vraag 20: Bent $\mathrm{u}$ in de afgelopen 12 maanden van werkgever veranderd?

$$
\begin{aligned}
& 1=j a \\
& 2=\text { nee }
\end{aligned}
$$

Vraag 21: Op welke wijze heeft u uw huidige functie verworven? Vul het juiste codenummer in. $U$ kunt slechts één codenummer invulien.

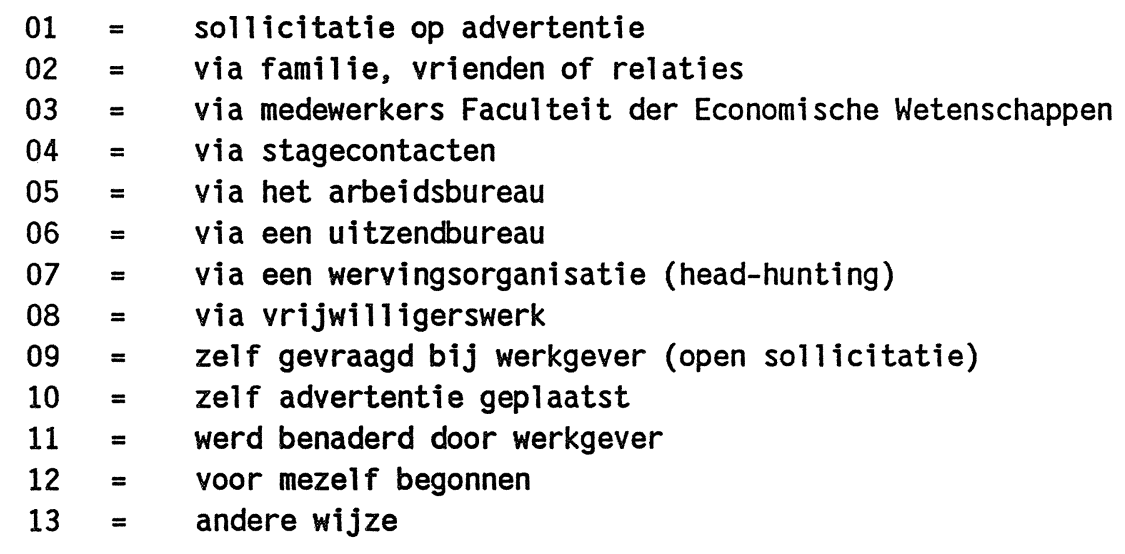

Vraag 22: In welk dienstverband bent $u$ thans werkzaam?

1 = werkzaam in loondienst

2 = werkzaam als zelfstandige voor eigen rekening of risico (eigen bedrijf of free-lance)

3 = werkzaam in een gezinsbedrijf; niet in loondienst

Vraag 23: Vul het totaal aantal maanden in waarop uw aanstelling betrekking heeft. Diegenen die een aanstelling hebben van meer dan 5 jaar noteren codenummer 99.

Vraag 24: Hoeveel uren per week werkt u gewoonlijk? Noteer het (gemiddelde) aantal arbeidsuren. Laat de uren door overwerk en voor nevenfuncties buiten beschouwing.

Vraag 25: Op het inlegvel vindt $u$ een schema van beroepsgroepen zoals die door het CBS worden gehanteerd. Binnen een hoofdcategorie vindt $u$ de naam van een bepaalde beroepsgroep, het betreffende codenummer en enkele voorbeelden van beroepen die tot deze beroepsgroep behoren. Vul op de basisvragenkaart het codenummer in dat het beste past bij uw werkzaamheden in uw huidige functie.

Vraag 26: Noteer de naam van uw huidige functie op de aangegeven lijn. 
Vraag 27: Aan hoeveel mensen geeft $u$, binnen de organisatie waar $u$ werkzaam bent, leiding? Noteer het juiste codenummer.

$\begin{array}{ll}0 & =\text { geen leiding aan andere personen } \\ 1 & =\text { leiding aan } 1-4 \text { personen } \\ 2 & =\text { leiding aan } 5-9 \text { personen } \\ 3 & =\text { leiding aan } 10-19 \text { personen } \\ 4 & =1 \text { leiding aan } 20-49 \text { personen } \\ 5 & =\text { leiding aan } 50 \text { of meer personen }\end{array}$

Vraag 28: Hoeveel bedraagt uw bruto inkomen per maand in uw huidige functie bij een volledige werkweek (exclusief toeslagen voor overwerk, 13e maand en vakantie)? Vul het codenummer van de betreffende categorie in.

$1=$ minder dan $f 1.500,--$
$2=f 1.500,--$ tot $f 2.000,--$
$3=$ f $2.000,--$ tot $f 2.500,--$
$4=$ f $2.500,--$ tot $f 3.000,--$
$5=$ f $3.000,--$ tot $f 3.750,--$
$6=$ f $3.750,--$ tot $f 5.000,--$
$7=$ f $5.000,--$ tot $f 7.500,--$
$8=$ f $7.500,--$ tot $f 12.500,--$
$9=$ f $12.500,--$ of meer

Vraag 29: In wat voor een soort instelling, praktijk of bedrijf bent $u$ thans werkzaam? op het inlegvel vindt $u$ een schema van branchegroepen zoals die door het CBS worden gehanteerd. Binnen een hoofdcategorie vindt $u$ de naam van een bepaalde branchegroep en het betreffende codenummer. Vul op de basisvragenkaart het codenummer in dat het beste past bij de diensten, c.q. produkten die door de instelling, de praktijk of het bedrijf waar $u$ werkzaam bent worden geleverd.

Vraag 30: Noteer naam en adres van de instelling, de praktijk of het bedrijf waar of van waaruit u werkt. Het gaat om de vestiging waar u werkzaam bent.

Vraag 31: Noteer op de aangegeven lijn de belangrijkste dienst/produkt die door de instelling, de praktijk of het bedrijf waar $u$ werkzaam bent, wordt geleverd.

Vraag 32: Hoeveel mensen werken er bij uw instelling, praktijk of bedrijf? Althans voor zover in de vestiging waar u werkzaam bent.
$1=$ minder dan 10 personen
$2=10$ tot en met 49 personen
$3=50$ tot en met 99 personen
$4=100$ personen of meer

De volgende vragen zijn bedoeld voor iedereen.

Vraag 33: Heeft $u$ in de afgelopen 4 weken naar een baan voor uzelf gezocht? Zo ja, op welke wijze(n)? Vul juiste codenummer(s) in. Er zijn maximaal 6 antwoorden mogelijk.

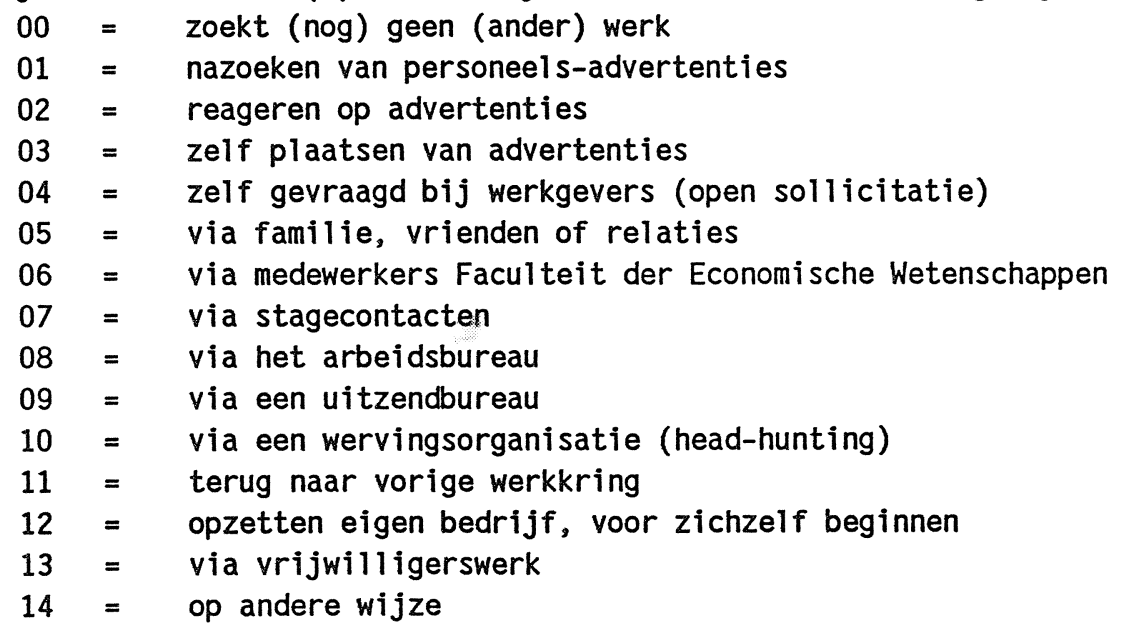


Vraag 34: Als u nu een (meer) geschikte baan zou vinden, kunt u dan binnen 2 weken beginnen?

$$
\begin{aligned}
& 1=\text { ja } \\
& 2=\text { nee }
\end{aligned}
$$

Vraag 35: Heeft $u$ in de afgelopen 12 maanden een opleiding gevolgd? Indien $u$ meerdere opleidingen heeft gevolgd, noteert $u$ de aard, de richting en de naam van de opleiding met het grootste aantal lesuren. De aard en de richting kunt $u$ invullen aan de hand van de volgende codenummers. Indien $u$ in de afgelopen 12 maanden géén opleiding heeft gevolgd, vul dan voor de aard het cijfer $\underline{0}$ en voor de richting de cijfers $\underline{00}$ in.

aard:

$\overline{1}=$ middelbaar beroepsonderwijs (voltijd)

2 = hoger beroepsonderwijs (voltijd)

3 = wetenschappelijk onderwijs (voltijd)

4 = middelbare deeltijdopleiding

$5=$ hogere deeltijdopleiding

$6=$ wetenschappelijke deeltijdopleiding

7 = een ander soort opleiding

\section{richting:}

$01=$ opl. tot onderwijzend personeel
$02=$ talen,wijsbegeerte,geschiedenis
$03=$ theologie
$04=$ agrarisch
$05=$ wiskunde, natuurwetenschappen
$06=$ technisch
$07=$ transport, communicatie, verkeer
$08=$ medisch,paramedisch
$09=$ economisch, administratief, commercieel
$10=$ juridisch, bestuurlijk
$11=$ sociaal-cultureel
$12=$ persoonlijke/sociale verzorging
$13=$ kunstonderwijs
$14=$ overig

Vraag 36: Hieronder staan enkele activiteiten die voor afgestudeerden van de Rijksuniversiteit Limburg (mogelijk) worden georganiseerd. Voor welke van onderstaande activiteiten heeft u belangstelling? $U$ kunt meerdere codenummers noteren.

$0=$ geen van onderstaande activiteiten

$1=$ themadag voor afgestudeerde economen

2 = voorlichting geven aan studenten economie over praktijk na afstuderen

3 = reünie van jaar-en/of studiegenoten

$4=$ deelname aan sollicitatiecursus

$5=$ opname in sollicitantenbank

$6=$ opzetten vacaturebank

$7=$ notatie in jaarlijkse adressenlijst voor afgestudeerde economen

$8=$ tijdschrift voor afgestudeerden aan de Rijksuniversiteit Limburg

Vraag 37: Wenst u een samenvattend verslag van het onderzoek te ontvangen?

$\begin{array}{lll}1 & = & j a \\ 2 & = & \text { nee }\end{array}$


BEROEPSGROEPEN ECONOMEN

codenummer beroepsgroep

0281

BEDRIJFSKUNDIGEN

0823
0830
0850

Bedrijfsorganisatiedeskundige

ACTUARISSEN

Actuaris, (levens)verzekeringswiskundige

AUTOMATISERINGSDESKUNDIGEN/STATISTICI

0901

0902

0903

0904

0905

1101

1102

1103

1104

3314

1310

1390

1944

2010

Systeemanalist, (administratieve) automatiseringsdeskundige

Statistisch/wiskundig medewerker

\section{ECONOMEN}

Economist, (bedrijfs)econoom, sociaal-economisch onderzoeker

Economisch adviseur (nijverheidsconsulent, beleggingsadviseur e.d.)

Marketing-specialist

Assistent-econoom

Marketing-assistent

\section{ACCOUNTANTS}

Accountant (accountantsbureau)

Accountant-administratieconsulent

Bedrijfs/rijksaccountant

Belastingconsulent

Ass istent-accountant/controller

\section{DOCENTEN}

Docent aan onderwijsinstelling

Hoofd van onderwijsinstelling e.a. onderwijsk. functies

\section{PERSONEELSORGANISATIEDESKUNDIGEN}

Functie-analist, personeelsorganisatie-adviseur e.d.

BELEIDVOERENDE EN HOGERE LEIDINGGEVENDE FUNCTIES BIJ OPENBAAR BESTUUR

Leden bestuurscolleges openbaar bestuur

Beleidvoerende en leidinggevende hoofdambtenaren bij openbaar bestuur e.d., diplomatieke vertegenwoordigers

bijv. directeur overheidsdienst, ambassadeur

BELEIDVOERENDE EN HOGERE LEIDINGGEVENDE FUNCTIES NIET BIJ OPENBAAR BESTUUR, HANDEL, HORECA EN LANDBOUW

2110 Directeuren NV, BV, coöperaties, stichtingen, verenigingen, overheidsbedrijven

2120 Zelfstandige bedrijfshoofden

2130

Bedrijfsleiders, algemene leiding

Bedrijfsleiders, produktie

Overige hogere leidinggevende functies

2190

bijv. hoofd afdeling verkoop, marketing, financiële zaken 
BEROEPSGROEPEN ECONOMEN

codenummer beroepsgroep

3000

3100

ADMINISTRATIEVE FUNCTIES

3394

Toezichthoudend-leidinggevend administratief personeel

bijv. chef de bureau

Uitvoerende hoofdambtenaren

bijv. uitvoerend hoofdambtenaar belastingzaken, economische zaken e.d., secretaris van (inter)gouvernementale dienst, organisatie of commissie

Boekhouders, kassiers

Kostprijs/begrotingscalculatoren

Middelbare en hogere bankemployées

bijv. accountmanager, beleggings/kredietadviseur, chef

financiering/kredietverlening

Bijkantoorhouders bank

3397

Bankemployées n.e.g.

Belastingambtenaren/assistenten

3990

Overige administratieve functies

4010

COMMERCIELE FUNCTIES

4020

Directeuren groothandel en tussenhandel

Bedrijfsleiders groothandel en tussenhandel

4110

bijv. salesmanager, exportmanager

Directeuren detailhande 1

4120

bijv. directeur warenhuis

Bedrijfsleiders detailhandel

4220

bijv. rayonleider, verkoopleider

4710

Makelaars/commissionairs in roerende goederen

$4900 \quad$ Overige commerciële functies

Verzekeringsagenten/inspecteurs, makelaars in onroerend goed, commissionairs in effecten, e.d

0000

\section{ANDERE BEROEPSGROEPEN}

Overige beroepsgroepen 
BRANCHEGROEPEN ECONOMEN

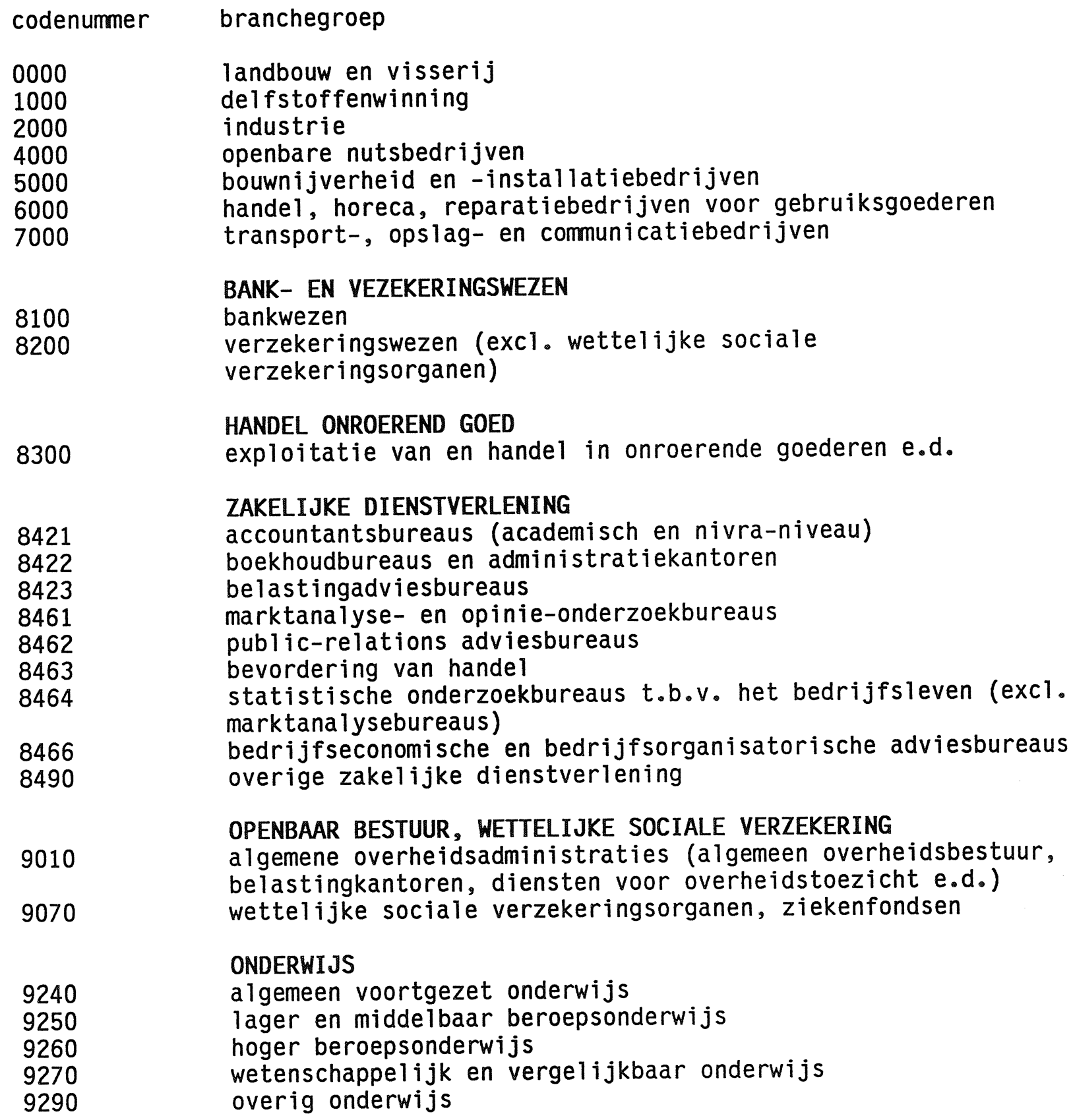

ZAKELIJKE DIENSTVERLENING

accountantsbureaus (academisch en nivra-niveau)

boekhoudbureaus en administratiekantoren

belastingadviesbureaus

marktanalyse- en opinie-onderzoekbureaus

public-relations adviesbureaus

bevordering van handel

statistische onderzoekbureaus t.b.v. het bedrijfsleven (excl. marktanalysebureaus)

bedrijfseconomische en bedrijfsorganisatorische adviesbureaus overige zakelijke dienstverlening

OPENBAAR BESTUUR, WETTELIJKE SOCIALE VERZEKERING

algemene overheidsadministraties (algemeen overheidsbestuur, belastingkantoren, diensten voor overheidstoezicht e.d.) wettelijke sociale verzekeringsorganen, ziekenfondsen

\section{ONDERWIJS}

algemeen voortgezet onderwijs

lager en middelbaar beroepsonderwijs

hoger beroepsonderwijs

wetenschappelijk en vergelijkbaar onderwijs

overig onderwijs

BEDRIJFS- EN WERKNEMERSORGANISATIES, RESEARCHINSTELLINGEN publ iekrechtelijke bedrijfsorganen

werkgevers- en ondernemersorganisaties

werknemersorganisaties

beroepsorganisaties

research- en wetenschappelijke instellingen (excl. universiteiten, hogescholen)

overige sociale organisaties

bijv. maatschappij voor nijverheid en handel, milieuverenigingen, politieke partijen e.d.

DIENSTVERLENING N.E.G. overige dienstverlening 

Beste econoom,

Het is nu al weer ruim een jaar geleden, dat $u$ de Faculteit der Economische Wetenschappen van de Rijksuniversiteit Limburg (RL) heeft verlaten. Wij zijn dan ook geïnteresseerd in de ervaringen die $u$ het afgelopen jaar heeft opgedaan. Bijvoorbeeld of $u$ na uw universitaire opleiding een baan heeft kunnen vinden. Om dit aan de weet te komen vragen wij u om mee te werken aan een periodiek loopbaanonderzoek onder afgestudeerden van de RL.

Door het invullen van de vragenlijst draagt $u$ er toe bij dat wij onze opleiding beter kunnen afstemmen op de praktijk. Deze gegevens zijn belangrijk voor jongeren die nog een studiekeuze moeten maken. Onze huidige en toekomstige studenten kunnen dan zien welke richtingen je met economische wetenschappen op kunt.

In dit loopbaanonderzoek werkt de Faculteit der Economische Wetenschappen samen met het Researchcentrum voor Onderwijs en Arbeidsmarkt (ROA) van de RL. De coördinatie van dit onderzoekproject is voorlopig in handen van het ROA. Op termijn zal echter worden gestreefd naar een onafhankelijke stichting. Deze stichting zal de universiteit behulpzaam zijn bij het ontplooien van activiteiten ten behoeve van afgestudeerden aan de RL. Als $u$ wilt deelnemen aan deze activiteiten kunt $u$ dat in de vragenlijst aangeven.

De door $\mathrm{u}$ verstrekte gegevens zullen anoniem voor het bovengenoemde loopbaanonderzoek worden gebruikt.

Bij de meeste vragen zijn de antwoordmogelijkheden al voorgedrukt. $U$ wordt verzocht om het getal te omcirkelen dat hoort bij het antwoord dat voor $u$ van toepassing is. Fouten kunt $u$ corrigeren met een kruis door het foute getal en een cirkel om het juiste getal.

De ingevulde vragenlijst kunt $u$ in de bijgevoegde antwoordenveloppe zonder postzegel sturen naar het ROA. Liefst zo snel mogelijk. Over enkele maanden zal een samenvattend verslag van het loopbaanonderzoek verschijnen. Indien $u$ daarvoor belangstelling heeft kunt $u$ dit kenbaar maken in de vragenlijst. Meer informatie kunt u krijgen bij dhr. G. Ramaekers, ROA, Postbus 616, 6200 MD Maastricht, telefoon $043-888852$.

We hopen dat u mee wilt werken aan dit loopbaanonderzoek. Alvast hartelijke dank en veel succes in de toekomst.

Met vriendelijke groet,

Researchcentrum voor

Onderwijs en Arbeidsmarkt

Prof.dr. J.A.M. Heijke

Drs. G.W.M. Ramaekers 



\section{Vragenlijst Economen}

De vragen $1 \mathrm{t} / \mathrm{m} 7$ alleen invullen voorzover bovenstaande gegevens onvolledig of onjuist zijn voorgedrukt

1. Naam + voorletters

(gehuwde vrouwen dienen hier hun meisjesnaam te vermelden)

2. Straatnaam en huisnummer :

3. Postcode en woonplaats

4. Land

5. Telefoon

6. Geboortejaar

: 19

7. Geslacht 


\section{Instructies voor het invullen van de volgende vragen!}

U wordt verzocht om het getal te omcirkelen dat hoort bij het antwoord dat voor $u$ van toepassing is. Er is steeds maar één antwoord mogelijk, tenzij anders is aangegeven. Fouten kunt u corrigeren met een kruis door het foute getal en een cirkel om het juiste getal. 
8. Hoogste met diploma afgesloten opleiding vóór uw afstuderen aan de $\mathrm{RL}$ als econoom.
1 VWO
2 HBO-opleiding met diploma, welk diploma:
(bijvoorbeeld HEAO)
3 WO-opleiding met doctoraaldiploma, welk diploma:
(bijvoorbeeld biochemie)
4 andere vooropleiding, welke:

9. Studie-/afstudeerrichting(en) aan de RL waarvoor u uw doctoraaldiploma heeft behaald. (meerdere antwoorden zijn mogelijk)

\section{Studie-/afstudeerrichting}

1 geneeskunde

2 gezondheidswet. / BB

3 gezondheidswet. / BW

4 gezondheidswet. / BGK

5 gezondheidswet. / FT

6 gezondheidswet. / GGK

7 gezondheidswet. / GVO

8 gezondheidswet. / VW

9 nederlands recht

10 economie / AE, specialisatie:

11 economie / BE, specialisatie

12 economie / KE, specialisatie

13 economie / IM , specialisatie:

14 economie / vrij doctoraal wanneer doctoraaldiploma behaald?

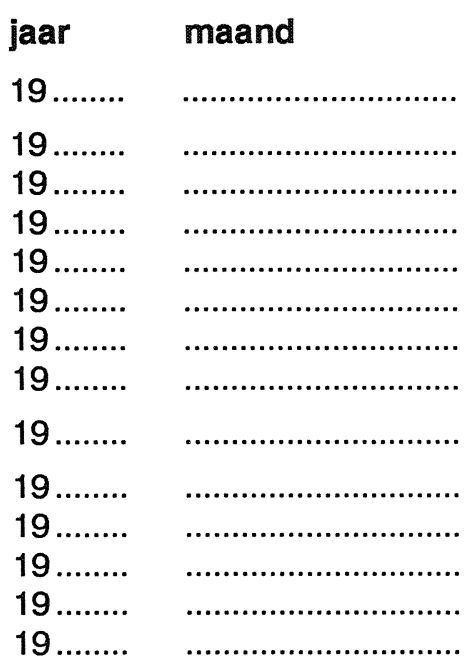

\section{Werkervaring vóor/tijdens de studie aan de RL}

10. Werkervaring vóór/tijdens uw studie economie aan de RL. Het gaat hier om betaald werk. (indien meerdere antwoorden van toepasssing zijn, omcirkel dan het hoogste cijfer)

0 geen werkervaring/vakantiewerk/weekendwerk

1 part-time/full-time baan hooguit 1 jaar; op niet-economisch gebied

2 part-time/full-time baan hooguit 1 jaar; op economisch gebied

3 part-time/full-time baan langer dan 1 jaar; op niet-economisch gebied

4 part-time/full-time baan langer dan 1 jaar; op economisch gebied

11. Heeft u gewerkt als studentassistent?

1 ja, in het bij vraag 10 omcirkelde betaalde werk

2 ja, in ander werk

3 nee

12. Niet-betaalde werkervaring.

(meerdere antwoorden zijn mogelijk)

1 bestuurlijke ervaring

2 vrijwilligerswerk op niet-economisch gebied (niet bestuurlijk)

3 vrijwilligerswerk op economisch gebied (niet bestuurlijk)

4 geen of andere dan bovenstaande ervaring 
13. Omcirkel de maand van het jaar 1988 waarin $u$ het doctoraaldiploma heeft ontvangen én de maand waarin u de vragenlijst invult. Noteer vervolgens achter iedere tussenliggende maand het codenummer dat het beste past bij uw dagelijkse bezigheden in de desbetreffende maand. $U$ kunt de bezigheden met behulp van onderstaande codenummers aangeven:

1 = betaald werk; $\mathrm{u}$ heeft een werkkring, bedrijf of praktijk (zie ook vraag 14)

2 = dienstplichtig militair (eerste oefening) of vervangende dienstplicht

3 = scholier, student

4 = huisvrouw/huisman

5 = arbeidsongeschikt; geheel of gedeeltelijk

6 = onbetaald werk met behoud van uitkering, vrijwilligerswerk

7 = werkloos

8 = gepensioneerd, renteniert, vervroegd pensioen

9 = andere situatie

1988

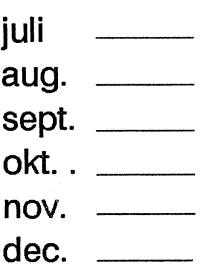

1989
jan.
febr.
maart
april
mei
juni
juli
aug.
sept.
okt
nov.
dec.

1990

jan.

febr.

maart

april

mei

juni

14. Deze vraag betreft uw huidige situatie. Als u onderstaande mogelijkheden bekijkt, waartoe rekent u zich dan? Omcirkel het codenummer dat het beste past bij uw huidige situatie.

Er is slechts één antwoord mogelijk.

1 betaald werk; $u$ heeft een werkkring, bedrijf of praktijk;

. werkt in loondienst

. werkt voor eigen rekening of risico

. werkt als gezinslid mee in het bedriff van echtgenoot/ouders

. werkt op een sociale werkplaats

. in opleiding bij een bedrijf of instelling maar met loon of salaris

. stagiair met loon of salaris

2 dienstplichtig militair (eerste oefening) of vervangende dienstplicht

3 scholier, student

4 huisvrouw/huisman

5 arbeidsongeschikt; geheel of gedeeltelijk

6 onbetaald werk met behoud van uitkering, vrijwilligerswerk

7 werkloos

8 gepensioneerd, renteniert, vervroegd pensioen

9 andere situatie, namelijk:

\section{BIJ CODENUMMER 1 GAAT U VERDER MET VRAAG 16.}

BIJ DE OVERIGE CODENUMMERS GAAT U VERDER MET VRAAG 15.

15. Vervult u naast uw huidige bezigheden, die u bij vraag 14 heeft omcirkeld, ook nog betaald werk?
$1 \quad$ ja
GA VERDER MET VRAAG 16
2 nee
GA VERDER MET VRAAG 30 


\section{INDIEN U MEER DAN ÉÉN BAAN HEEFT, HEBBEN DE VRAGEN 16 TOT EN MET 29 ALLEEN BETREKKING OP DE BAAN MET DE MEESTE ARBEIDSUREN}

16. Bent $\mathrm{u}$ na het afstuderen aan de $\mathrm{RL}$ al eens van werkgever veranderd?

1 ja, belangrijkste reden:

2 nee

17. Bent $\mathrm{u}$ na het afstuderen aan de RL bij uw huidige werkgever van functie veranderd?

1 ja, belangrijkste reden:

2 nee

18. Op welke wijze heeft $u$ uw huidige functie verworven? Omcirkel het juiste codenummer.

Er is slechts één antwoord mogelijk.

1 sollicitatie op advertentie

2 via familie, vrienden of relaties

3 via medewerkers Faculteit der Economische Wetenschappen

4 via studentassistentschap

5 via stagecontacten

6 via het arbeidsbureau

7 via een uitzendbureau

8 via een wervingsorganisatie (head-hunting)

9 via vrijwilligerswerk

10 zelf gevraagd bij werkgever (open sollicitatie)

11 zelf advertentie geplaatst

12 werd benaderd door werkgever

13 zelf bedrijf/praktijk opgezet

14 andere wijze, namelijk:

19. In welk dienstverband bent $u$ thans werkzaam?

1 in loondienst

2 als zelfstandige voor eigen rekening of risico

20. Noteer het totaal aantal maanden waarop uw aanstelling betrekking heeft. Diegenen die een aanstelling hebben van meer dan 5 jaar noteren nummer 99 .

totaal aantal maanden:

21. Hoeveel uren per week werkt u gewoonlijk? Noteer het (gemiddelde) aantal arbeidsuren. Laat de uren door overwerk en voor nevenfuncties buiten beschouwing.

gemiddeld: $\quad$ uren

22. Op het inlegvel vindt $u$ een schema van beroepsgroepen zoals die door het CBS worden gehanteerd. Binnen een hoofdcategorie vindt $u$ de naam van een bepaalde beroepsgroep met het desbetreffende codenummer. Noteer hieronder het codenummer dat het beste past bij uw werkzaamheden in uw huidige functie.

codenummer beroepsgroep: 
23. Noteer de naam van uw huidige functie.

naam functie:

24. Aan hoeveel mensen geeft $u$, binnen de organisatie waar u werkzaam bent, leiding?
$0 \quad$ geen leiding aan andere personen
$1 \quad$ leiding aan 1 - 4 personen
2 leiding aan $5-9$ personen
$3 \quad$ leiding aan $10-19$ personen
4 leiding aan 20 - 49 personen
$5 \quad$ leiding aan $\mathbf{5 0}$ of meer personen

25. Hoeveel bedraagt uw bruto inkomen per maand in uw huidige functie bij een volledige werkweek? (exclusief toeslagen voor overwerk, 13e maand en vakantie)

$\begin{array}{ll}1 & \text { minder dan f } 1.500,-- \\ 2 & \text { f } 1.500,-- \text { tot f } 2.000,-- \\ 3 & \text { f } 2.000,-- \text { tot f } 2.500,-- \\ 4 & \text { f } 2.500,-- \text { tot f } 3.000,-- \\ 5 & \text { f } 3.000,-- \text { tot f } 3.750,-- \\ 6 & \text { f } 3.750,-- \text { tot f } 5.000,-- \\ 7 & \text { f } 5.000,-- \text { tot } f 7.500,-- \\ 8 & \text { f } 7.500,-- \text { tot f } 12.500,-- \\ 9 & \text { f } 12.500,-- \text { of meer }\end{array}$

26. In wat voor een soort instelling, praktijk of bedrijf bent $u$ thans werkzaam? Op het inlegvel vindt $u$ een schema van branchegroepen zoals die door het CBS worden gehanteerd. Binnen een hoofdcategorie vindt $u$ de naam van een bepaalde branchegroep met het desbetreffende codenummer. Noteer hieronder het codenummer dat het beste past bij de diensten, c.q. produkten die door de instelling, de praktijk of het bedrijf waar u werkzaam bent worden geleverd.

codenummer branchegroep:

27. Noteer naam, adres, postcode en plaats van de instelling, de praktijk of het bedrijf waar of van waaruit $u$ werkt. Het gaat om de vestiging waar u werkzaam bent.

naam

adres

postcode en plaats:

28. Noteer de belangrijkste dienst/produkt die door de instelling, de praktijk of het bedrijf waar u werkzaam bent, wordt geleverd. Het gaat om de vestiging waar $u$ werkzaam bent.

naam dienst/produkt:

29. Hoeveel mensen werken er bij uw instelling, praktijk of bedrijf? Het gaat om de vestiging waar u werkzaam bent.

1 minder dan 10 personen

210 tot en met 49 personen

350 tot en met 99 personen

4100 personen of meer 
30. Bent $u$ op zoek naar een (andere) betaalde baan voor uzelf?

1 ja, belangrijkste reden:

2 nee

31. Als u nu een (meer) geschikte baan zou vinden, kunt $u$ dan binnen 2 weken beginnen?

$1 \quad$ ja

2 nee, belangrijkste reden:

32. Heeft u ná uw doctoraalexamen economie nog een opleiding of cursus gevolgd? Indien u meerdere opleidingen/cursussen volgt (heeft gevolgd), geeft $u$ de aard, de richting en de naam aan van de opleiding/cursus met het grootste aantal lesuren. De aard en de richting kunt $u$ aangeven door de juiste codenummers te omcirkelen. Indien $u$ na het doctoraalexamen géén opleiding/cursus heeft gevolgd, omcirkel dan bij de aard het cijfer 0 en bij de richting de cijfers 00 .

aard: $\quad 0=$ geen verder onderwijs

1 = middelbaar beroepsonderwijs

2 = hoger beroepsonderwijs

$3=$ wetenschappelijk onderwijs, eerste fase

4 = wetenschappelijk onderwijs, tweede fase

$5=$ post-hoger onderwijs

$6=$ een ander soort opleiding of cursus

richting: $\quad 00=$ geen verder onderwijs

$01=$ opl. tot onderwijzend personeel

02 = talen, wijsbegeerte, geschiedenis

$03=$ theologie

$04=$ agrarisch

$05=$ wiskunde, natuurwetenschappen

$06=$ technisch

$07=$ transport, telecommunicatie, verkeer

$08=$ medisch, paramedisch

09 = economisch, administratief, commercieel

$10=$ juridisch, bestuurlijk

$11=$ sociaal-cultureel

$12=$ persoonlijke/sociale verzorging

$13=$ kunstonderwijs

$14=$ overig onderwijs

naam van de opleiding/cursus:

(bijvoorbeeld: PBNA - bedrijfskunde)

33. Hieronder staan enkele activiteiten die voor afgestudeerden van de RL (mogelijk) worden georganiseerd. Omcirkel de aktiviteiten waarvoor u belangstelling heeft.

Meerdere antwoorden zijn mogelijk.

0 geen van onderstaande activiteiten

1 themadag voor afgestudeerde economen

2 voorlichting geven aan studenten economie over praktijk na afstuderen

3 reünie van jaar- en/of studiegenoten

4 post academisch onderwijs voor economen namelijk:

5 opname in sollicitantenbestand

6 notatie in jaarlijkse adressenlijst voor afgestudeerde economen

7 tijdschrift voor afgestudeerden aan de RL 
34. Wenst $u$ een samenvattend verslag van het onderzoek te ontvangen?

1 ja

2 nee

Hartelijk dank voor uw medewerking!

Eventuele opmerkingen: 


\title{
Beroepsgroepen Economen
}

\author{
Codenummer Beroepsgroep \\ Bedrijfskundigen \\ 0281 Bedrijfsorganisatiedeskundige \\ Actuarissen \\ 0823 \\ Actuaris, (levens) verzekeringswiskundige \\ Automatiseringsdeskundigen/statistici \\ Systeemanalist, (administratieve) automatiseringsdeskundige \\ Statistisch/wiskundig medewerker

\section{Economen} \\ Economist, (bedrijfs)econoom, sociaal-economisch onderzoeker \\ Economisch adviseur (nijverheidsconsulent, beleggingsadviseur e.d.) \\ Marketing-specialist \\ Assistent-econoom \\ Marketing-assistent

\section{Accountants} \\ Accountant (accountantsbureau) \\ Accountant-administratieconsulent \\ Bedriffs/rijksaccountant \\ Belastingconsulent \\ Assistent-accountant/controller

\section{Docenten} \\ Docent aan onderwijsinstelling \\ Hoofd van onderwijsinstelling e.a. onderwijskundige functies \\ Personeelsorganisatiedeskundigen \\ Functie-analist, personeelsorganisatie-adviseur e.d.
}

\section{Beleidvoerende en hogere leidinggevende functies bij openbaar bestuur}

\section{Leden bestuurscolleges openbaar bestuur}

Beleidvoerende en leidinggevende hoofdambtenaren bij openbaar bestuur e.d., diplomatieke vertegenwoordigers bijv. directeur overheidsdienst, ambassadeur

\section{Beleidvoerende en hogere leidinggevende functies niet bij openbaar bestuur, handel, horeca en landbouw}

Directeuren NV, BV, coöperaties, stichtingen, verenigingen, overheidsbedrijven
Zelfstandige bedrifshoofden

Bedrijfsleiders, algemene leiding

Bedriffsleiders, produktie

Overige hogere leidinggevende functies bijv. hoofd afdeling verkoop, marketing, financiële zaken

\section{Administratieve functies}

Toezichthoudend-leidinggevend administratief personeel bijv. chef de bureau

Uitvoerende hoofdambtenaren bijv. uitvoerend hoofdambtenaar belastingzaken, economische zaken e.d., secretaris van (inter)gouvernementale dienst, organisatie of commissie

Boekhouders, kassiers

Kostprijs/begrotingscalculatoren

Middelbare en hogere bankemployés bijv. accountmanager, beleggings/kredietadviseur,

chef financiering/kredietverlening

Bijkantoorhouders bank

Bankemployés n.e.g.

Belastingambtenaren/assistenten

Overige administratieve functies

\section{Commerciële functies}

Directeuren groothandel en tussenhandel

Bedrijfsleiders groothandel en tussenhandel bijv. salesmanager, exportmanager

Directeuren detailhandel bijv. directeur warenhuis

Bedriffsleiders detailhandel bijv. rayonleider, verkoopleider

Makelaars/commissionairs in roerende goederen

Verzekeringsagenten/inspecteurs, makelaars in onroerend goed, commissionairs in effecten,

Overige commerciële functies

\section{Andere beroepsgroepen}

Overige beroepsgroepen 


\title{
Branchegroepen Economen
}

\author{
Codenummer Branchegroep
}

0000

1000

2000

4000

5000

6000

7000

8100

8200

8300

8421

8422

8423

8461

8462

8463

8464

8466

8490

9010

9070

9240

9250

9260

9270

9290

9710

9720

9730

9740

9750

9790

Landbouw en visserij

Delfstoffenwinning

Industrie

Openbare nutsbedrijven

Bouwnijverheid en -installatiebedrijven

Handel, horeca, reparatiebedrijven voor gebruiksgoederen

Transport-, opslag- en communicatiebedrijven

\section{Bank- en verzekeringswezen}

Bankwezen

Verzekeringswezen (excl. wettelijke sociale verzekeringsorganen)

\section{Handel onroerend goed}

Exploitatie van en handel in onroerende goederen e.d.

\section{Zakelijke dienstverlening}

Accountantsbureaus (academisch en nivra-niveau)

Boekhoudbureaus en administratiekantoren

Belastingadviesbureaus

Marktanalyse- en opinie-onderzoekbureaus

Public-relations adviesbureaus

Bevordering van handel

Statistische onderzoekbureaus t.b.v. het bedrijfsleven (excl. marktanalysebureaus)

Bedrijfseconomische en bedrijfsorganisatorische adviesbureaus

Overige zakelijke dienstverlening

\section{Openbaar bestuur, wettelijke sociale voorziening}

Algemene overheidsadministraties (algemeen overheidsbestuur, belastingkantoren, diensten voor overheidstoezicht e.d.)

Wettelijke sociale verzekeringsorganen, ziekenfondsen

\section{Onderwijs}

Algemeen voortgezet onderwijs

Lager en middelbaar beroepsonderwijs

Hoger beroepsonderwijs

Wetenschappelijk en vergelijkbaar onderwijs

Overig onderwijs

\section{Bedrijfs- en werknemersorganisaties, researchinstellingen}

Publiekrechtelijke bedrijfsorganen

Werkgevers- en ondernemersorganisaties

Werknemersorganisaties

Beroepsorganisaties

Research- en wetenschappelijke instellingen (excl. universiteiten, hogescholen)

Overige sociale organisaties bijv. maatschappij voor nijverheid en handel, milieuverenigingen, politieke partijen e.d.

Dienstverlening n.e.g.

Overige dienstverlening 
Geachte mevrouw/mijnheer,

Zoals u zich wellicht kunt herinneren bent $u$ vorig jaar benaderd om een kaart met gegevens in te vullen ten behoeve van het periodieke loopbaanonderzoek onder afgestudeerden van de Rijksuniversiteit Limburg (RL). Ook dit jaar zouden wij uw medewerking aan deze jaarlijkse enquête op prijs stellen.

In dit loopbaanonderzoek werken de afzonderlijke faculteiten samen met het Researchcentrum voor Onderwijs en Arbeidsmarkt (ROA) van de RL. Het ROA is verbonden aan de Faculteit der Economische Wetenschappen van de RL. De coördinatie van dit onderzoekproject is voorlopig in handen van het ROA. Op termijn wordt echter gestreefd naar een onafhankelijke stichting. Deze stichting zal de universiteit behulpzaam zijn bij het ontplooien van activiteiten ten behoeve van afgestudeerden aan de RL. Als u wilt deelnemen aan deze activiteiten kunt $u$ dat op de jaarkaart aangeven.

De door $u$ op de jaarkaart ingevulde gegevens zullen anoniem voor het bovengenoemde loopbaanonderzoek worden gebruikt.

De ingevulde jaarkaart kunt $u$ in de bijgevoegde antwoordenveloppe zonder postzegel sturen naar het ROA. Liefst zo snel mogelijk. Over enkele maanden zal een samenvattend verslag van het loopbaanonderzoek verschijnen. Indien $u$ daarvoor belangstelling heeft kunt $u$ dit kenbaar maken op de jaarkaart. Meer informatie kunt u krijgen bij dhr. G. Ramaekers, ROA, Postbus 616,6200 MD Maastricht, telefoon 043 - 888852 .

We hopen dat $u$ opnieuw mee wil werken door de jaarkaart in te vullen en op te sturen. Alvast hartelijk dank en veel succes in uw verdere toekomst.

\section{INSTRUCTIES VOOR HET INVULLEN VAN DE VRAGEN}

Lees eerst onderstaande instructies, voordat $u$ de vragen gaat beantwoorden!

De enquête bestaat uit een jaarkaart en een bijbehorende toelichting op de vragen. Alle antwoorden noteert $u$ alléén op de jaarkaart. Lees bij iedere vraag eerst de bijbehorende toelichting. Noteer daarna het antwoord. Deze toelichting heeft $u$ nodig om te weten welke codenummers u bij het invullen van de jaarkaart dient te gebruiken.

Een aantal antwoorden op de jaarkaart is reeds voorgedrukt aan de hand van gegevens uit voorafgaande jaren. Alleen gegevens die niet, onvolledig of onjuist zijn genoteerd, dient $u$ uitsluitend in de daarvoor bestemde hokjes in te vullen. Noteer de antwoorden altijd in blokletters en neem codenummers uit de toelichting bij de vragen nauwkeurig over. De verwerking van de jaarkaarten gaat dan veel vlotter.

ALVAST HARTELIJK DANK VOOR UW MEDEWERKING! 

1. naam:

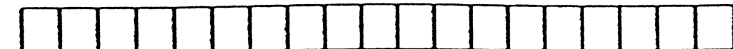
2. voorletters:
3. straatnaam:

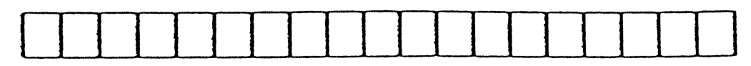
4. hui snummer:
5. woonplaats:

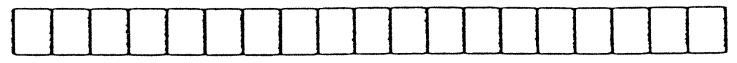
6. postcode:

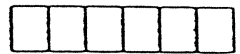
7. Iand:

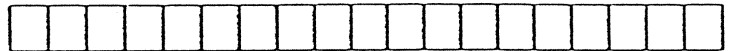
8. telefoon:
9. gepromoveerd:
10. huidige situatie:

11. werkzoekend: $\square$

12. bezigheden oktober $1988 \mathrm{t} / \mathrm{m}$ september 1989:

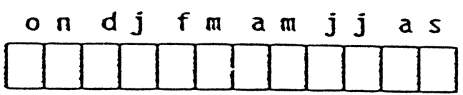

Niet elke vraag hoeft voor $u$ relevant te zijn (zie toelichting)
13. veraridering functie:
14. verandering werkgever:
15. functiewerving:
$\square$
16. dienstverband:
17. tijdsduur aansteliing: $\square$
18. arbeidsuren:

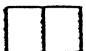

19. beroepsgroep:

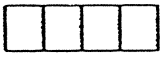

20. functienaam:

21. leiding:

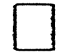

22. inkomen:

23. branchegroep:

24. dienst/produkt:

2:. naari + werkadres:

2€. p:rsoneel somvang:

2i. 1:arkzoekmethode $(n)$ :

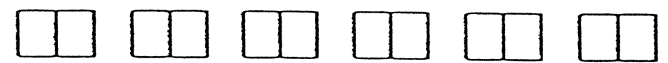

28. beschikbaarheid:

29. opleiding: aard: $\square$ richting: $\square$ naam:

30. deelname aktiviteiten: $\square \square \square \square \square \square \square \square$

31. verslag onderzoek:

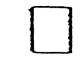


ALLEEN DE ANTWOORDEN DIE NIET, ONJUIST OF ONVOLLEDIG ZIJN VOORGEDRUKT INVULLEN! GEBRUIK UITSLUITEND DE DAARVOOR BESTEMDE HOKJES.

Vraag 1: Gehuwde vrouwen dienen hier alleen hun meisjesnaam te vermelden.

Vraag 8: Plaats tussen netnummer en abonneenummer een liggend streepje (-).

Vraag 9: Bent u gepromoveerd tot dr.?

$\begin{array}{lll}1 & = & \text { ja } \\ 2 & =\text { nee }\end{array}$

Vraag 10: Deze vraag betreft uw huidige situatie. Als u onderstaande mogelijkheden bekijkt, waartoe rekent u zich dan? Vul het codenummer in dat het beste past bij uw huidige situatie. $U$ kunt slechts één codenummer invullen.

1 = betaald werk; $u$ heeft werkkring, bedrijf of praktijk

- werkt in loondienst

- werkt voor eigen rekening of risico

werkt als gezinslid mee in het bedrijf van echtgenoot/ouders

werkt op een sociale werkplaats of aanvullende werken

- in opleiding bij een bedrijf of instelling maar met loon of salaris

$2=$ dienstplichtig militair (eerste oefening) of vervangende dienstplicht

$3=$ scholier, student

$4=$ huisvrouw/huisman

5 = gepensioneerd, renteniert, vervroegd pensioen

6 = arbeidsongeschikt; geheel of gedeeltelijk

7 = onbetaald werk met behoud van uitkering, vrijwilligerswerk

$8=$ werkloos

$9=$ andere situatie

Bij codenummer 1 gaat $u$ na het beantwoorden van vraag 11 en 12 verder met vraag 13; indien u meer dan één baan heeft, hebben de vragen 13 tot en met 26 alléén betrekking op de baan met de meeste arbeidsuren.

Bij de overige codenummers gaat $u$ na het beantwoorden van vraag 11 en 12 verder met vraag 27.

Vraag 11: Bent u op zoek naar een (andere baan) voor uzelf?

$1=$ ja

Vraag 12: Noteer voor iedere maand in de periode oktober $1988 \mathrm{t} / \mathrm{m}$ september 1989 het codenummer dat het beste past bij de dagelijkse bezigheden die $u$ toen had.

1 = betaald werk; u heeft een werkkring, bedrijf of praktijk (zie ook vraag 10)

2 = dienstplichtig militair (eerste oefening) of vervangende dienstplicht

$3=$ scholier, student

$4=$ huisvrouw/huisman

$5=$ gepensioneerd, renteniert, vervroegd pensioen

$6=$ arbeidsongeschikt; geheel of gedeeltelijk

$7=$ onbetaald werk met behoud van uitkering, vrijwilligerswerk

$8=$ werkloos

$9=$ andere situatie

Vraag 13: Bent $u$ in de afgelopen 12 maanden van functie veranderd?

$\begin{array}{lll}1 & = & \text { ja } \\ 2 & = & \text { nee }\end{array}$

Vraag 14: Bent $u$ in de afgelopen 12 maanden van werkgever veranderd?

$\begin{array}{lll}1 & = & \text { ja } \\ 2 & = & \text { nee }\end{array}$


Vraag 15: Op welke wijze heeft $u$ uw huidige functie verworven? Vul het juiste codenummer in. $U$ kunt slechts één codenummer invullen.

$01=$ sollicitatie op advertentie
$02=$ via familie, vrienden of relaties
$03=$ via medewerkers Faculteit der Economische Wetenschappen
$04=$ via stagecontacten
$05=$ via het arbeidsbureau
$06=$ via een uitzendbureau
$07=$ via een wervingsorganisatie (head-hunting)
$08=$ via vrijwilligerswerk
$09=$ zelf gevraagd bij werkgever (open sollicitatie)
$10=$ zelf advertentie geplaatst
$11=$ werd benaderd door werkgever
$12=$ voor mezelf begonnen
$13=$ op andere wijze

Vraag 16: In welk dienstverband bent $u$ thans werkzaam?

1 = werkzaam in loondienst

2 = werkzaam als zelfstandige voor eigen rekening of risico (eigen bedrijf of free-lance)

3 = werkzaam in een gezinsbedrijf; niet in loondienst

Vraag 17: Vul het totaal aantal maanden in waarop uw huidige aanstelling betrekking heeft. Diegenen die een aanstelling hebben van meer dan 5 jaar noteren codenummer 99.

Vraag 18: Hoeveel uren per week werkt u gewoonlijk? Noteer het (gemiddelde) aantal arbeidsuren. Laat de uren door overwerk en voor nevenwerkzaamheden buiten beschouwing.

Vraag 19: Op het inlegvel vindt $u$ een schema van beroepsgroepen zoals die door het CBS worden gehanteerd. Binnen een hoofdcategorie vindt $u$ de naam van een bepaal de beroepsgroep, het betreffende codenummer en enkele voorbeelden van beroepen die tot deze beroepsgroep behoren. Vul op de jaarkaart het codenummer in dat het beste past bij uw werkzaamheden in uw huidige functie.

Vraag 20: Noteer de naam van uw huidige functie op de aangegeven lijn.

Vraag 21: Aan hoeveel mensen geeft $u$, binnen de organisatie waar u werkzaam bent, leiding? Noteer het juiste codenummer.

$0=$ geen leiding aan andere personen
$1=$ leiding aan $1-4$ personen
$2 \quad=$ leiding aan $5-9$ personen
$3=$ leiding aan $10-19$ personen
$4=$ leiding aan $20-49$ personen
$5=$ leiding aan 50 of meer personen

Vraag 22: Hoeveel bedraagt uw bruto inkomen per maand in uw huidige functie bij een volledige werkweek (exclusief toeslagen voor overwerk, 13e maand en vakantie)? Vul het codenummer van de betreffende categorie in.

$1=$ minder dan f $1.500,--$
$2=$ f $1.500,--$ tot $f 2.000,--$
$3=$ f $2.000,--$ tot $f 2.500,--$
$4=$ f $2.500,--$ tot $f 3.000,--$
$5=$ f $3.000,--$ tot $f 3.750,--$
$6=$ f $3.750,--$ tot $f 5.000,--$
$7=$ f $5.000,--$ tot $f 7.500,--$
$8=$ f $7.500,--$ tot $f 12.500,--$
$9=$ f $12.500,--$ of meer

Vraag 23: In wat voor een soort instelling, praktijk of bedrijf bent $u$ thans werkzaam? op het inlegvel vindt $u$ een schema van branchegroepen zoals die door het CBS worden gehanteerd. Binnen een hoofdcategorie vindt $u$ de naam van een bepaal de branchegroep en het betreffende codenummer. Vul op de jaarkaart het codenummer in dat het beste past bij de diensten, c.q. produkten die door de instelling, de praktijk of het bedrijf waar u werkzaam bent worden geleverd.

Vraag 24: Noteer op de aangegeven iijn de belangrijkste dienst/produkt die door de instelling, de praktijk of het bedrijf waar u werkzaam bent wordt geleverd. 
Vraag 25: Noteer naam en adres van de instelling, de praktijk of het bedrijf waar of van waaruit $u$ werkt. Het gaat om de vestiging waar u werkzaam bent.

Vraag 26: Hoeveel mensen werken er bij uw instelling, praktijk of bedrijf? Althans voor zover in de vestiging waar u werkzaam bent.

$1=$ minder dan 10 personen
$2=10$ tot en met 49 personen
$3=50$ tot en met 99 personen
$4=100$ personen of meer

De volgende vragen zijn bedoeld voor iedereen.

Vraag 27: Heeft $u$ in de afgelopen 4 weken naar een baan voor uzelf gezocht? Zo ja, op welke wijze(n)? Vul juiste codenummer(s) in. Er zijn maximaal 6 antwoorden mogelijk.

$00=$ zoekt (nog) geen werk

01 = nazoeken van personeels-advertenties

$02=$ reageren op advertenties

$03=$ zelf plaatsen van advertenties

$04=$ zelf gevraagd bij werkgevers (open sollicitatie)

$05=$ via familie, vrienden of relaties

$06=$ via medewerkers Faculteit der Economische Wetenschappen

$07=\quad$ via stagecontacten

$08=$ via het arbeidsbureau

$09=$ via een uitzendbureau

10 = via een wervingsorganisatie (head-hunting)

11 = terug naar vorige werkkring

12 = opzetten eigen bedrijf, voor zichzelf beginnen

13 = via vrijwilligerswerk

$14=$ op andere wijze

Vraag 28: Als u nu een (meer) geschikte baan zou vinden, kunt u dan binnen 2 weken beginnen?

$\begin{array}{lll}1 & = & \text { ja } \\ 2 & =\text { nee }\end{array}$

Vraag 29: Heeft $u$ in afgelopen 12 maanden een opleiding gevolgd? Indien u meerdere opleidingen heeft gevolgd, noteert $u$ de aard, de richting en de naam van de opleiding met het grootste aantal lesuren. De aard en de richting kunt $u$ invullen aan de hand van de volgende codenummers. Indien $u$ in de afgelopen 12 maanden géén opleiding heeft gevolgd, vul dan voor de aard het cijfer $\underline{0}$ en voor de richting de cijfers 00 in.

aard:

$\begin{array}{lll}\overline{1} & = & \text { middelbaar beroepsonderwijs (voltijd) } \\ 2 & = & \text { hoger beroepsonderwijs (voltijd) } \\ 3 & = & \text { wetenschappelijk onderwijs (voltijd) } \\ 4 & =\text { middelbare deeltijdopleiding } \\ 5 & = & \text { hogere deeltijdopleiding } \\ 6 & = & \text { wetenschappelijke deeltijdopleiding } \\ 7 & = & \text { een ander soort opleiding }\end{array}$

richting:

$01=$ opl. tot onderwijzend personeel
$02=$ talen,wijsbegeerte, geschiedenis
$03=$ theologie
$04=$ agrarisch
$05=$ wiskunde, natuurwetenschappen
$06=$ technisch
$07=$ transport, communicatie, verkeer
$08=$ medisch, paramedisch
$09=$ economisch, administratief, commercieel
$10=$ juridisch, bestuurlijk
$11=$ sociaal-cultureel
$12=$ persoonlijke/sociale verzorging
$13=$ kunstonderwijs
$14=$ overig


$-4-$

Vraag 30: Hieronder staan enkele activiteiten die voor afgestudeerden van de Rijksuniversiteit Limburg (mogelijk) worden georganiseerd. Voor welke van onderstaande activiteiten heeft $u$ belangstelling? $U$ kunt meerdere codenummers noteren.

$0=$ geen van onderstaande activiteiten

1 = themadag voor afgestudeerde economen

2 = voorlichting geven aan studenten economie over praktijk na afstuderen

3 = reünie van jaar-en/of studiegenoten

4 = deelname aan sollicitatiecursus

$5=$ opname in sollicitantenbank

$6=$ opzetten vacaturebank

7 = notatie in jaarlijkse adressenlijst voor afgestudeerde economen

$8=$ tijdschrift voor afgestudeerden aan de Rijksuniversiteit Limburg

Vraag 31: Wenst $u$ een samenvattend verslag van het onderzoek te ontvangen?

$$
1=\mathrm{ja}
$$

$2=$ nee 
BEROEPSGROEPEN ECONOMEN

$\begin{array}{ll}\text { codenummer } & \text { beroepsgroep } \\ 0281 & \begin{array}{l}\text { BEDRIJFSKUNDIGEN } \\ \text { Bedrijfsorganisatiedeskundige }\end{array} \\ 0823 & \begin{array}{l}\text { ACTUARISSEN } \\ \text { Actuaris, (levens) verzekeringswiskundige }\end{array}\end{array}$

0830

0850

0901

0902

0903

0904

0905

1101

1102

1103

1104

3314

1310

1390

1944

2010

AUTOMATISERINGSDESKUNDIGEN/STATISTICI

Systeemanalist, (administratieve) automatiseringsdeskundige

Statistisch/wiskundig medewerker

\section{ECONOMEN}

Economist, (bedrijfs)econoom, sociaal-economisch onderzoeker

Economisch adviseur (nijverheidsconsulent, beleggingsadviseur e.d.)

Marketing-specialist

Assistent-econoom

Marketing-assistent

\section{ACCOUNTANTS}

Accountant (accountantsbureau)

Accountant-administratieconsulent

Bedrijfs/rijksaccountant

Belastingconsulent

Assistent-accountant/controller

\section{DOCENTEN}

Docent aan onderwijsinstelling

Hoofd van onderwijsinstelling e.a. onderwijsk. functies

\section{PERSONEELSORGANISATIEDESKUNDIGEN}

Functie-analist, personeelsorganisatie-adviseur e.d.

BELEIDVOERENDE EN HOGERE LEIDINGGEVENDE FUNCTIES BIJ OPENBAAR BESTUUR

2020

Leden bestuurscolleges openbaar bestuur

Beleidvoerende en leidinggevende hoofdambtenaren bij openbaar bestuur e.d., diplomatieke vertegenwoordigers

bijv. directeur overheidsdienst, ambassadeur

BELEIDVOERENDE EN HOGERE LEIDINGGEVENDE FUNCTIES NIET BIJ OPENBAAR BESTUUR, HANDEL, HORECA EN LANDBOUW

2110 Directeuren NV, BV, coöperaties, stichtingen, verenigingen, overheidsbedrijven

Zelfstandige bedrijfshoofden

2130

Bedrijfsleiders, algemene leiding

2140

Bedrijfsleiders, produktie

2190

Overige hogere leidinggevende functies

bijv. hoofd afdeling verkoop, marketing, financiële zaken 
BEROEPSGROEPEN ECONOMEN

codenummer beroepsgroep

3000

ADMINISTRATIEVE FUNCTIES

3100 Uitvoerende hoofdambtenaren

Toezichthoudend-leidinggevend administratief personeel

bijv. chef de bureau

bijv. uitvoerend hoofdambtenaar belastingzaken, economische zaken e.d., secretaris van (inter)gouvernementale dienst, organisatie of commissie Boekhouders, kassiers

Kostprijs/begrotingscalculatoren

Middelbare en hogere bankemployées

bijv. accountmanager, beleggings/kredietadviseur, chef

financiering/kredietverlening

Bijkantoorhouders bank

3396

Bankemployées n.e.g.

3397

Belastingambtenaren/assistenten

3990

Overige administratieve functies

4010

COMMERCIELE FUNCTIES

4020

Directeuren groothandel en tussenhandel

Bedrijfsleiders groothandel en tussenhandel

4110

bijv. salesmanager, exportmanager

Directeuren detailhandel

4120

bijv. directeur warenhuis

Bedrijfsleiders detailhandel

4220

bijv. rayonleider, verkoopleider

Makelaars/commissionairs in roerende goederen

4710

4900

Verzekeringsagenten/inspecteurs, makelaars in onroerend goed, commissionairs in effecten, e.d

Overige commerciële functies

0000

ANDERE BEROEPSGROEPEN

Overige beroepsgroepen 


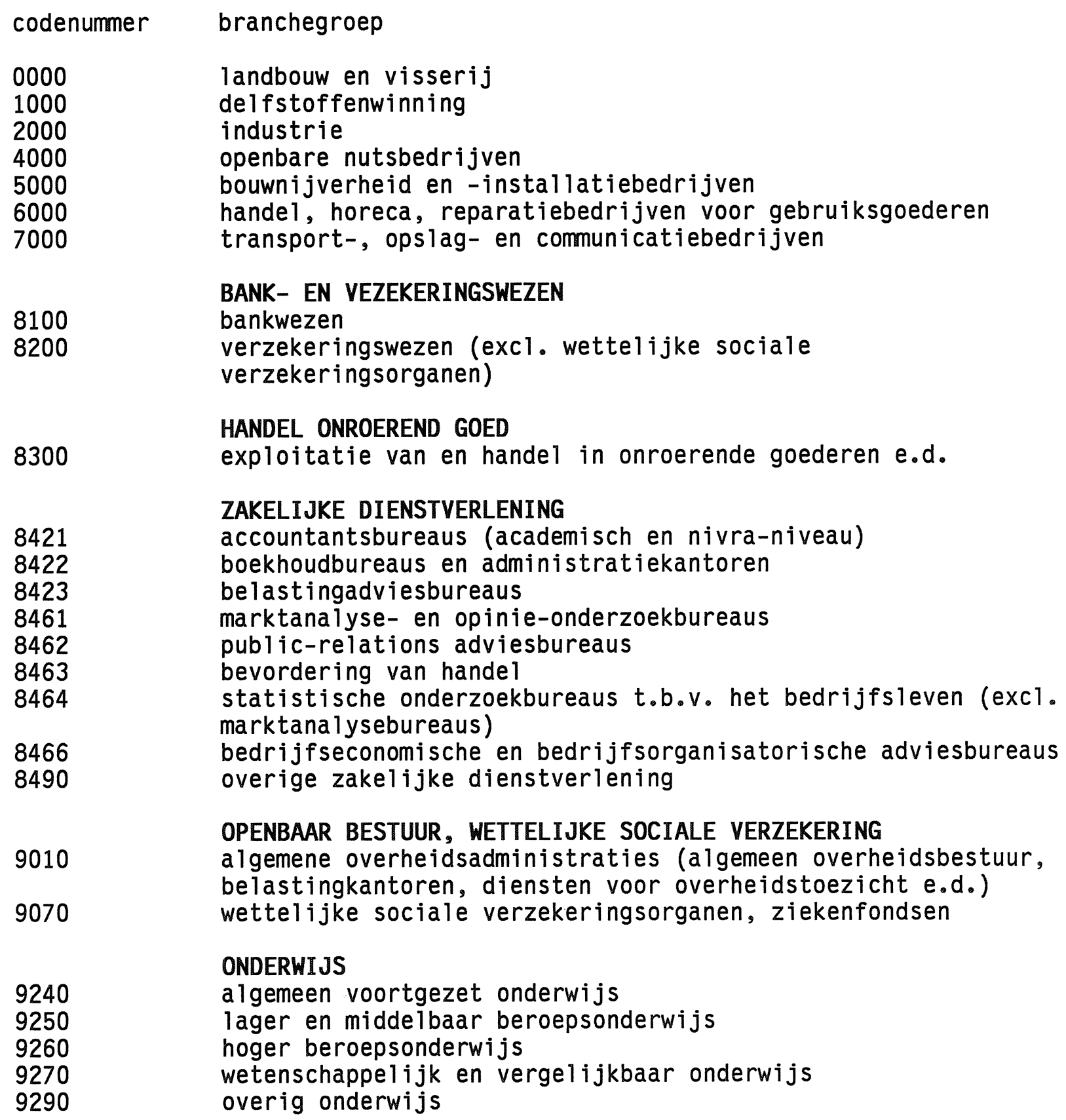

ONDERWIJS

algemeen voortgezet onderwijs

lager en middelbaar beroepsonderwijs

hoger beroepsonderwijs

wetenschappelijk en vergelijkbaar onderwijs

overig onderwijs

BEDRIJFS- EN WERKNEMERSORGANISATIES, RESEARCHINSTELLINGEN publ iekrechtelijke bedrijfsorganen

werkgevers- en ondernemersorganisaties

werknemersorganisaties

beroepsorganisaties

research- en wetenschappelijke instellingen (excl. universiteiten, hogescholen)

overige sociale organisaties

bijv. maatschappij voor nijverheid en handel, milieuverenigingen, politieke partijen e.d.

DIENSTVERLENING N.E.G. overige dienstverlening 